\title{
Conceptual Design of a Shipping Container for Transporting High-Level Waste by Railroad
}
P. L. Peterson
R. E. Rhoads

December 1978

Prepared for the U.S. Department of Energy under Contract EY-76-C-06-1830

Pacific Northwest Laboratory Operated for the U.S. Department of Energy by Battelle Memorial Institute 


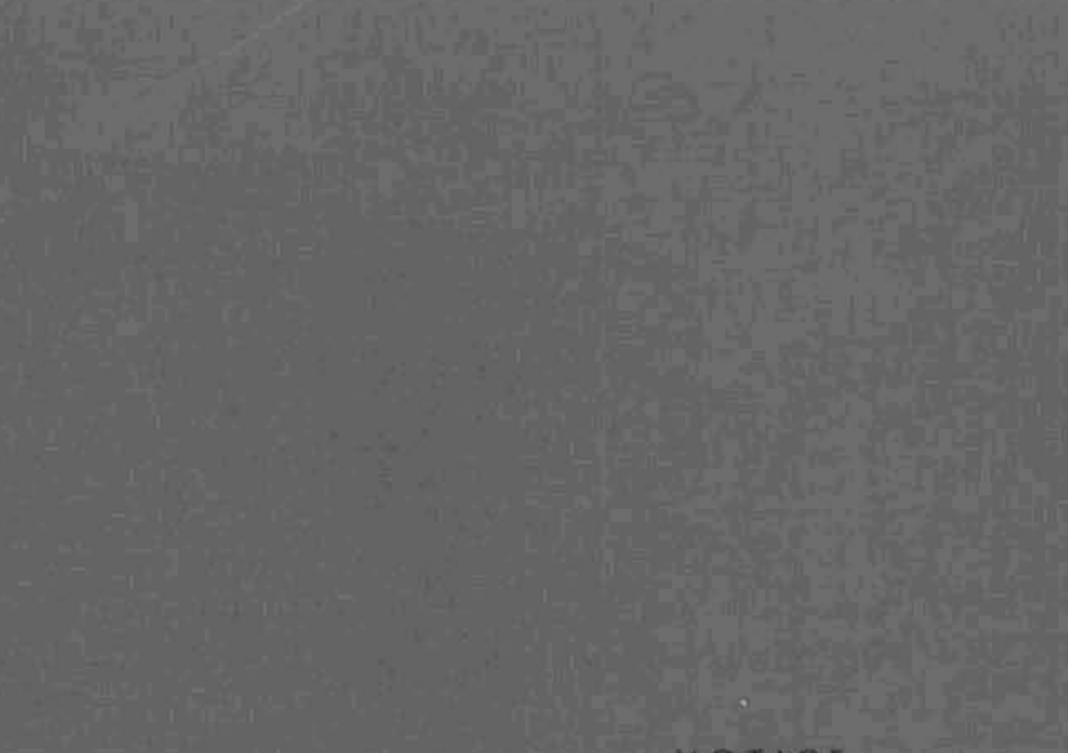

\title{
NOTICE
}

This report was prepared as an account of work sponsored by the United States Government. Neither the United States nor the Department of Energy, nor any of their employees, nor any of their contractors, subcontractors, or their employees, makes any warranty, express or implied, or assumes any legal liability or responsibility for the accuracy, completeness or usefulness of any information, apparatus, product or process disclosed, or represents that its use would not infringe privately owned rights.

The views, opinions and conclusions contained in this report are those of the contractor and do not necessarily represent those of the United States Government or the United States Department of Energy.

\author{
PACIFIC NORTHWEST LABORATORY \\ operated by \\ BATTELLE \\ for the \\ UNITED STATES DEPARTMENT OF ENERGY \\ Under Contract EY-76-C-06-7830
}
Printed in the United States of America
Available from
National Technical Information Service
United States Department of Commerce
5285 Port Royal Road
Springlield, Virginia 2275i

Price: Printed Copy

$\because$ Micrafiche 53.00

\begin{tabular}{cc} 
& NIIS \\
•Pages & Selling Price \\
$001-025$ & $\$ 4.00$ \\
$026-050$ & $\$ 4.50$ \\
$051-075$ & $\$ 5.25$ \\
$076-100$ & $\$ 6.00$ \\
$101-125$ & $\$ 6.50$ \\
$126-150$ & $\$ 7.25$ \\
$151-175$ & $\$ 9.00$ \\
$176-200$ & $\$ 9.00$ \\
$201-225$ & $\$ 9.25$ \\
$276-250$ & $\$ 9.50$ \\
$251-205$ & $\$ 10.75$ \\
$226-300$ & $\$ 11.00$ \\
\hline
\end{tabular}


PNL-2244

CONCEPTUAL DESIGN OF A SHIPPING CONTAINER FOR TRANSPORTING HIGH-LEVEL WASTE BY RAILROAD

P. L. Peterson

R. E. Rhoads

December 1978

Prepared for

the U.S. Department of Energy under Contract EY-76-C-06-1830

Pacific Northwest Laboratory

Richland, Washington 99352 
P

. 
CONTENTS

1.0 INTRODUCTION

2.0 DESIGN CONSTRAINTS

2.1 FEDERAL REGULATIONS . . . . . . . . . . . . . . . . . . . 6

2.2 CHARACTERISTICS OF SOLIDIFIED HIGH-LEVEL WASTE . • • . • $\quad 8$

2.2.1 SHLW Canister Configuration . . . . . . . . 12

2.3 RAILROAD TRANSPORTATION SYSTEM CONSIDERATIONS • • • • • 12

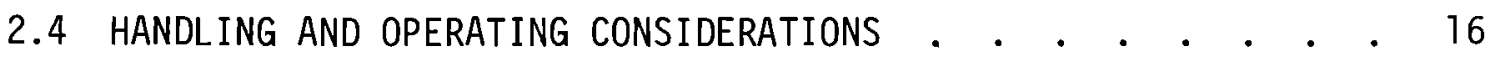

3.0 CONCEPTUAL SOLIDIFIED HIGH-LEVEL WASTE CASK SYSTEM • • • • • • 19

3.1 CASK/RAILCAR DESCRIPTION

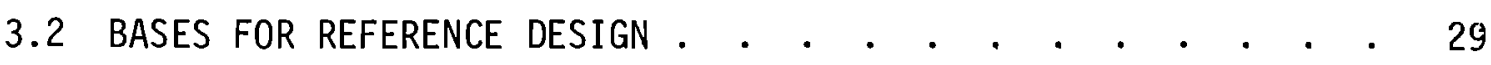

3.2.1 Cask Structure . . . . . . . . . . . . . 30

3.2.2 Heat Dissipation . . . . . . . • . . • . . 30

3.2.3 Shielding . . . . . . . • . . . . . . . 33

3.2.4 Cask Handling and Tiedown Systems . . . . . . . . . 36

4.0 ALTERNATE CONSIDERATIONS IN CASK SYSTEM DESIGN . . . . . . . . 39

APPENDIX A - Description of Cask Models . . . . . . . . . . . 45

APPENDIX B - Thermal Analysis of Conceptual Cask . . . . . . . . 51

APPENDIX C - Mechanical Analysis of Conceptual Cask . . . . . . 57 


\section{FIGURES}

2.1 Geometric Configuration of Reference Waste Canister . . . . 13

2.2 Standard Railroad Clearance Outline . . . . . . . . . . 15

3.1 Conceptual Solidified High-Level Waste Shipping Cask and Railcar . . . . . . . . . . . . . . 20

3.2 Conceptual Solidified High-Level Waste Shipping Cask Structural Details . . . . . . . . . . . . . . 23

3.3 Tiedown and Handling Systems of Conceptual HighLevel Waste Shipping Cask . . . . . . . . . . . . . 27

4.1 Temperature at Selected Points Throughout the Cask as a Function of Waste Age . . . . . . . . . . . 40

4.2 Loading Configurations for Canisters of Various Diameters in a $1.5 \mathrm{~m}$ Diameter Inner Cavity . . . . . . . 43

A.1 Photograph of HO Gauge (1/87) Scale Model of SHLW Cask and Railcar System. . . . . . . . . . . . . . 46

A.2 Photograph of the $1 / 10$ Scale Model of the SHLW Rail Cask . . . . . . . . . . . . . . . . . 47

A.3 Explanatory Poster to Accompany Cask Models . . . . . . . 48

A.4 Handout to Accompany Cask Models . . . . . . . . . . 49

B.1 Configuration Assumed for Steady State Thermal Analysis . • . 52

B.2 Configuration Assumed for Transient Thermal Analysis . . . . 53

C.1 Outer Shell Thickness vs. Weight of Cask to Cause Puncture . . 58

C.2 Configuration for Trunnion Structural Analysis . • • • • • 61

C.3 Forward Pedestal Assembly . . . . . . . . . . . . . 64 


\section{$\underline{\text { TABLES }}$}

2.1 Maximum Radiation Doses Permitted for a SHLW Cask $\quad$ • . . . $\quad 6$

2.2 Environmental Conditions for Normal Transport of Radioactive Materials . . . . . . . . . . . . . 7

2.3 Test Conditions for Type B Packaging $\quad . \quad$.

2.4 Reference Borosilicate Glass Characteristics . . . . . . . 9

2.5 Radiation and Heat Generation Properties of Reference Solidified High-Level Waste . • . . . • . . . . . . 11

2.6 Gamma Ray Energy Spectrum from Reference Solidified High-Level Waste . • . . . . . . . . . . . . . . 11

2.7 Tiedown Design Criteria . • • • • • • . . . . . . 17

3.1 Conceptual SHLW Cask Design Parameters . . . . . . . . . 21

3.2 Results of Thermal Analysis of Conceptual Cask Design . . . . 33

3.3 Typical Properties of Shielding Materials . . . . . . . . . 35

4.1 Comparison of Alternative Canister Sizes . . . . . . . . . 42

B.1 Results of Steady-State Thermal Analysis . . . . . . . . 54

B.2 Results of a Transient Thermal Analysis . • • • • • • • • 55 


\subsection{INTRODUCTION}

Reprocessing of spent fuel from commercial light water reactors (LWR's) has been deferred indefinitely while the international safeguards issues associated with plutonium extraction and recycle are being debated. Current reprocessing plant designs would extract the fission products and actinides from the spent fuel in an acidic solution. This solution is called high-level liquid waste (HLLW) and under current federal regulations, it must be converted to a thermally and chemically stable solid within five years of its generation and shipped to a federal repository for solidified high-level wastes (SHLW) within 10 years of the date that the waste is separated from the fuel. If it is eventually decided to proceed with the reprocessing option, much work remains to be done to develop commercial facilities and equipment to solidify the high level liquid waste (HLLW) produced during chemical reprocessing of LWR fuel; to transport the waste from the reprocessing plant to a federal radioactive waste repository; and to isolate the waste from the environment until the radioactivity has decayed to nonhazardous levels. The Department of Energy has conducted a variety of research activities in these areas to insure that reprocessing and waste disposal technology will be available if the decision to use this technology is made.

A shipping cask uniquely designed to transport SHLW from a reprocessing plant to a federal repository has not yet been developed. The amount of material that would be transported and the anticipated characteristics of the SHLW suggest that rail casks will be favored for this transportation because of cost and logistic considerations.

This document presents the results of a study to develop a conceptual design for a rail cask for transporting SHLW and to construct scale models of the conceptual cask with accompanying graphics for use at technical meetings and in public information displays. Two $1 / 10$ scale models of the conceptual cask and two HO gauge (1/87 scale) models of the cask/railcar system have been constructed. A description of the models and accompanying graphics is presented in Appendix A. 
The primary purpose of this document is to present the information developed for the conceptual cask design displayed in the models. Because of the similarities in the heat generation and radiation properties of SHLW and spent reactor fuel, the conceptual design presented is similar in many respects to the design of spent fuel casks currently in use.

The design of a shipping container for radioactive material is dependent on a variety of factors or design constraints, including federal regulations, the characteristics of the material to be transported, limitations of the transport mode, and operating considerations. Economics and logistics considerations dictate that a shipping cask should be able to transport the maximum volume of SHLW possible within these design constraints. The general approach used to develop the conceptual cask design was to:

- Review current technology in high-level waste solidification.

- Select a reference or baseline canister design and associated characteristics based on the current technology.

- Establish design constraints due to SHLW properties, the railroad transportation environment, and requirements for handling or storing the canisters.

- Identify design constraints imposed by current federal hazardous material transportation regulations.

- Review current technology in spent fuel casks.

- Conceptually design a system to maximize the volume of SHLW conveyed in light of the constraints identified.

Design constraints for a SHLW cask are discussed in detail in Section 2.0. A detailed description of the conceptual SHLW cask design is presented in Section 3.0. The bases for selecting key design characteristics are also discussed. Preliminary thermal and structural analyses were performed for the conceptual cask design. The results of these analyses are presented with calculational details in Appendices B and C. Design changes that would be required to accommodate waste with different physical or radiological characteristics are discussed in Section 4.0.

In the process of developing this conceptual design, it has become apparent that certain key parameters will control the final design of a 
SHLW shipping cask. It may also be beneficial to build a cask system that provides some flexibility in the contents that can be shipped. These insights and others that have evolved in developing the conceptual SHLW shipping cask design are presented in Section 4.0. 
•

. 


\subsection{DESIGN CONSTRAINTS}

The criteria for conceptual design of a cask system are developed by identifying an envelope of constraints within which the cask must be 1 icensed and operated. The constraints are defined by:

- the characteristics of the nuclear fuel cycle

- the physical properties of the SHLW

- handling requirements of the shipper and receiver

- physical and operational limits of the transportacion system

- federal hazardous material transportation regulations

- shipping cost considerations

- available technology

Many of these constraints are interdependent and the design process can be complex and involve many iterations to arrive at an optimum design. For example, economic considerations dictate that the number of containers of SHLW that can be shipped at one time be maximized. The number of canisters that can be placed in the cask is limited by the dimensions of the canisters and the useable volume in the cask. The outer dimensions and total weight of the cask are limited by physical and operating parameters of the railroad system and the useable volume of the cask is limited by shielding and cask strength requirments imposed by federal regulations. Shielding requirements in turn are determined by the characteristics of the waste and the amount of waste in each shipment. Shielding is also a very important contributor to overall cask weight. Heat transfer requirements of the cask are determined by the physical characteristics of the waste and the requirements of federal regulations for performance of the cask in normal transportation and in postulated accidents involving fire. The task of the designer is to use available technology to balance these interdependent factors in a costeffective manner.

A conceptual design represents the first attempt to describe a cask system that meets the requirements of these constraints. Much detailed 
engineering work remains to confirm the ideas presented in the conceptual design or to arrive at better solutions to the design problem. The design constraints that were considered most important for the development of a conceptual cask system are discussed in the remainder of this section.

\subsection{FEDERAL REGULATIONS}

Federal regulations dealing with the transportation of radioactive materials are found in 49CFR 170-199 and 10CFR 71. These regulations set forth requirements that protect the health and safety of the public and transportation workers during normal transportation and in severe transportation accidents. A cask for transporting large quantities of radioactive materials (such as SHLW) must meet all the requirements of the Department of Transportation (set forth in 49 CFR 170-199) and be licensed for use by the Nuclear Regulatory Commission (NRC) after a detailed review of the cask design and safety analysis reports. The federal transportation regulations essentially provide the envelope within which other design constraints can be met.

Federal regulations require that large quantities of radioactive material such as SHLW be transported in containers that meet the performance requirements of Type $B$ packaging. The regulations establish limits for radiation dose rates from the cask, set forth environmental conditions that the cask must be able to withstand in normal transportation and establish design criteria for cask safety during accidents. Radiation dose limits applicable to a SHLW cask are given in Table 2.1. Environmental conditions that might be encountered during normal transport are given in Table 2.2.

TAP.LE 2.1. Maximum Radiation Doses Permitted for a SHLW Cask ${ }^{(2)}$

- 1000 millirem per hour at three feet from the external surface of the package.

- 200 millirem per hour at any point on the external surface of the car or vehicle.

- 10 millirem per hour at six feet from the external surface of the car or vehicle.

- 2 millirem per hour at any normally occupied position in the car or vehicle 
TABLE 2.2. Environmental Conditigns for Normal Transport of
Radioactive Materials 3 (3)

- Heat - direct sunlight at an ambient temperature of $54^{\circ} \mathrm{C}$ in still air.

- Cold - an ambient temperature of $-40^{\circ} \mathrm{C}$ in still air and shade

- Pressure - one-half standard atmospheric pressure

- Vibration - normally incident to transport.

The Safety Analysis Report that is submitted to NRC to obtain a license for a Type B package must show that the cask can maintain its integrity through a series of tests designed to simulate the effects of a severe transportation accident. The test series is given in Table 2.3. Each of the three tests is applied sequentially in the order shown in the table. The cask must also be able to withstand a series of tests simulating the normal transport environment, but in general, a cask design that meets the accident test criteria will also meet the normal transport environment test criteria.

\section{TABLE 2.3. Test Conditions for Type B Packaging}

- Free drop - through a distance of $9.1 \mathrm{~m}$ onto an unyielding surface striking the surface in the position which would produce maximum damage.

- Puncture - a free drop through a distance of $1 \mathrm{~m}$ onto a cylindrical steel bar $15.2 \mathrm{~cm}$ in diameter with the edge rounded to a radius of $5.4 \mathrm{~mm}$. The length of the bar is selected for maximum damage (minimum length is $20.3 \mathrm{~cm}$ ). The bar is mounted on an unyielding horizontal surface and the package is dropped in a position expected to produce maximum damage.

- Thermal - exposure to the equivalent of a $300^{\circ} \mathrm{C}$ fire for 30 minutes with no artificial cooling for $3 \mathrm{hrs}$. after the exposure.

(a) Tests applied sequentially to determine cumulative effect on the package. Extracted from Reference 4. 
Federal regulations also require that surfaces of the cask that are accessible during transportation have a maximum temperature of $82^{\circ} \mathrm{C}$. (1) In casks such as a SHLW cask that provide a large heat removal capability, this requirement is often met by placing a protective screen over the cask before it is shipped.

\subsection{CHARACTERISTICS OF SOLIDIFIED HIGH-LEVEL WASTE}

Design of a solidified high-level waste shipping cask requires detailed information concerning the physical properties of the material to be shipped. Properties or characteristics required for input to the design include:

- geometric configuration (length and diameter) of the canister

- heat generation rate within the SHLW

- canister shell material and engineering properties

- gamma and neutron radiation intensities from SHLW

- SHLW engineering properties (density, thermal conductivity, etc.)

- canister handling configuration

Processes to solidify high-level liquide waste have not yet been demonstrated on a commercial scale. A variety of processes are in various stages of development around the world. (High-level waste solidification technology is reviewed in detail in Reference 5.) Since there is some uncertainty about the form and characteristics of the solidified high-level waste that might be produced at a commercial reprocessing plant, it was necessary to make assumptions about the waste characteristics in order to develop the conceptual SHLW cask design. The assumptions on waste properties presented in the remainder of this section are based on fuel cycle characteristics and HLW solidification technology that currently appears most likely to be used in the future. 
Present plans in the United States and many other countries are to convert high-level liquid waste to a vitrified product. The majority of HLW vitrification processes under consideration incorporate the waste products into either a borosilicate or phosphate glass. Properties of a typical borosilicate glass product selected as a reference product form for this study are shown in Table 2.4. The waste form shown in the table is produced by calcining the liquid waste to a dry oxide powder, then combining the waste oxides with inert glass formers at high temperature. The solid vitrified product results when the mixture cools.

TABLE 2.4. Reference Borosilicate Glass Characteristics

Composition

$\mathrm{SiO}_{2}$

$\mathrm{B}_{2} \mathrm{O}_{3}$

Alkali metal oxides

Other glass formers

Waste oxides

$\mathrm{Gd}_{2} \mathrm{O}_{3}$

Typical volume

Density

Thermal conductivity

Processing temperature
38 wt \%

11 wt \%

14 wt \%

7 wt \%

25 wt \%

5 wt \%

60 l/MTHM

$3.0 \mathrm{gm} / \mathrm{cm}^{3}$

$0.9-1.3 \mathrm{w} / \mathrm{m}-{ }^{\circ} \mathrm{C}$

$1050^{\circ} \mathrm{C}$ 
The composition and physical properties of high-level waste will vary with fuel cycle options, reactor type, fuel exposure history, waste cooling time, and reprocessing plant operating parameters. Reference high-level waste properties used for the conceptual cask design have been calculated using the ORIGEN computer code. $(6)$ An estimated reprocessing plant feed for the year 2000 has been used. The reprocessing plant feed is assumed to be $1 / 3$ BWR fuel with an average burnup of 25,000 MWd per MTU and 2/3 PWR fuel with an average burnup of 32,000 MWd per MTU. About $15 \%$ of the spent fuel contains recycled plutonium. The fuel is assumed to be reprocessed 1.5 years after reactor discharge. The reference high-level waste contains $0.5 \%$ of the uranium and plutonium, $0.1 \%$ of the iodine and bromine, $8 \%$ of the tritium, and none of the carbon or noble gases originally present in the fuel.

The radiation and heat generation properties of the solidified highlevel waste are two of the most important parameters in determining the cask design. The shipping cask must provide sufficient gamma and neutron radiation shielding to meet the regulatory requirements presented in Section 2.1 and provide heat removal capability to maintain temperatures in the waste and cask sufficiently low to prevent damage during shipment. A maximum permissible canister centerline temperature of $650^{\circ} \mathrm{C}$ was assumed, based on discussions with personnel at Pacific Northwest Laboratories involved in waste solidification studies.

The radiation and heat generation properties for the reference SHLW are shown in Tables 2.5 and 2.6. The variation in these properties with time after reprocessing is also shown. The heat generation rate due to radioactive decay within the SHLW declines significantly during the first five years following reprocessing of the spent fuel. Storage of SHLW at the federal repository is simplified as the heat generation rate declines. Thus, it is likely that the SHLW will be stored for a few years at the reprocessing plant before shipment. An average age of five years at the time of transportation was selected as a basis for the conceptual cask design. 
TABLE 2.5. Radiation and Heat Generation Properties of Reference Solidified High-Level Waste

\begin{tabular}{|c|c|c|c|}
\hline & Time Since & Reprocessing & (yrs.) \\
\hline Heat Generation (watts/l) ${ }^{(a)}$ & $\underline{0}$ & $\underline{5}$ & $\underline{10}$ \\
\hline Fission Products & 110 & 25 & 15 \\
\hline Actinides & 10 & 4 & 3 \\
\hline TOTAL (rounded) & 120 & 30 & 20 \\
\hline $\begin{array}{l}\text { Neutron Source }{ }^{(b)} \text { (neutrons } / \text { sec }-l \text { ) } \\
\text { Gamma Source (photons } / \text { sec }-l \text { ) }\end{array}$ & $1.8 \mathrm{E} 7$ & $1.4 \mathrm{E} 7$ & $1.2 \mathrm{E} 7$ \\
\hline Fission Products & $2.2 \mathrm{E} 14$ & $6.0 \mathrm{E} 13$ & $3.7 \mathrm{E} 13$ \\
\hline Actinides & $3.3 \mathrm{E} 11$ & $3.2 \mathrm{E} 11$ & $3.2 \mathrm{E} 11$ \\
\hline
\end{tabular}
(a) The reference waste canister holds about 1701 of SHLW.
(b) Primarily from spontaneous fission.

TABLE 2.6. Gamma Ray Energy Spectrum from Reference Solidified High-Level Waste

\begin{tabular}{|c|c|c|c|c|}
\hline \multirow[b]{2}{*}{ Mean } & \multirow[b]{2}{*}{ Gamma Energy (MeV) } & \multicolumn{3}{|c|}{$\frac{\text { Fraction of Total Gamma Source }}{\text { In Year Indicated }}$} \\
\hline & & $\underline{0}$ & $\underline{5}$ & 10 \\
\hline & $\begin{array}{l}.3 \\
.63 \\
1.1 \\
1.55 \\
1.99 \\
2.38 \\
2.75 \\
3.25 \\
3.7 \text { or greater }\end{array}$ & $\begin{array}{l}.13 \\
.82 \\
.04 \\
.01 \\
.004 \\
.001 \\
4.3 \mathrm{E}-5 \\
1.4 \mathrm{E}-6 \\
2.3 \mathrm{E}-9\end{array}$ & $\begin{array}{l}.04 \\
.93 \\
.03 \\
.005 \\
2.5 \mathrm{E}-4 \\
6.7 \mathrm{E}-5 \\
5.2 \mathrm{E}-6 \\
1.7 \mathrm{E}-7 \\
6.9 \mathrm{E}-9\end{array}$ & $\begin{array}{l}.04 \\
.93 \\
.03 \\
.002 \\
1.5 \mathrm{E}-5 \\
3.5 \mathrm{E}-6 \\
2.7 \mathrm{E}-7 \\
8.8 \mathrm{E}-9 \\
9.5 \mathrm{E}-9\end{array}$ \\
\hline
\end{tabular}




\subsubsection{SHLW Canister Configuration}

The dimensions and construction materials used for the SHLW canister may vary with the vitrification process used, the age of the waste when it is solidified, and storage and handling considerations. Dissipation of the heat generated within the SHLW requires a relatively large surface-to-volume ratio and short conduction paths to prevent centerline melting since the vitrified product has a relatively poor thermal conductivity. Processing considerations generally favor maximizing the volume in each canister for economic reasons. A right circular cylinder with a large length to diameter ratio is indicated to meet these constraints. Past feasibility studies of canister forms have considered diameters ranging between about 15 and $60 \mathrm{~cm}$, depending on the strength and age of the solidified product. (7) Lengths up to 3.0 meters or more have also been indicated.

The geometric configuration of the reference canister is shown in Figure 2.1. A diameter of $30 \mathrm{~cm}$ was selected for the reference canister. This value was selected as a typical diameter in Reference 7 and is intermediate to the range of values identified in high-level waste solidification process studies. A canister length of $3 \mathrm{~m}$ has been used. Allowance must be made for canister design features which reduce the overall volume such as a concave bottom, a necked-down upper section, a sealing plug, possible internal cooling fins, and head space due to processing considerations. A volume of waste equivalent to $80 \%$ of the maximum volume was used as an allowance for these factors. Thus, each reference canister will contain 0.17 cubic meters of solidified product. This is equivalent to the waste produced from reprocessing 3.3 metric tons of spent fuel.

The canister shell material was assumed to be a 300 series stainless steel between 6 and $12 \mathrm{~mm}$ thick. The canister diameter selected includes the shell material. The lifting lugs shown in Figure 2.1 for handling the canister were selected on the basis of simplicity in a visual display.

\subsection{RAILROAD TRANSPORTATION SYSTEM CONSIDERATIONS}

An initial guideline established for the conceptual cask system was to 


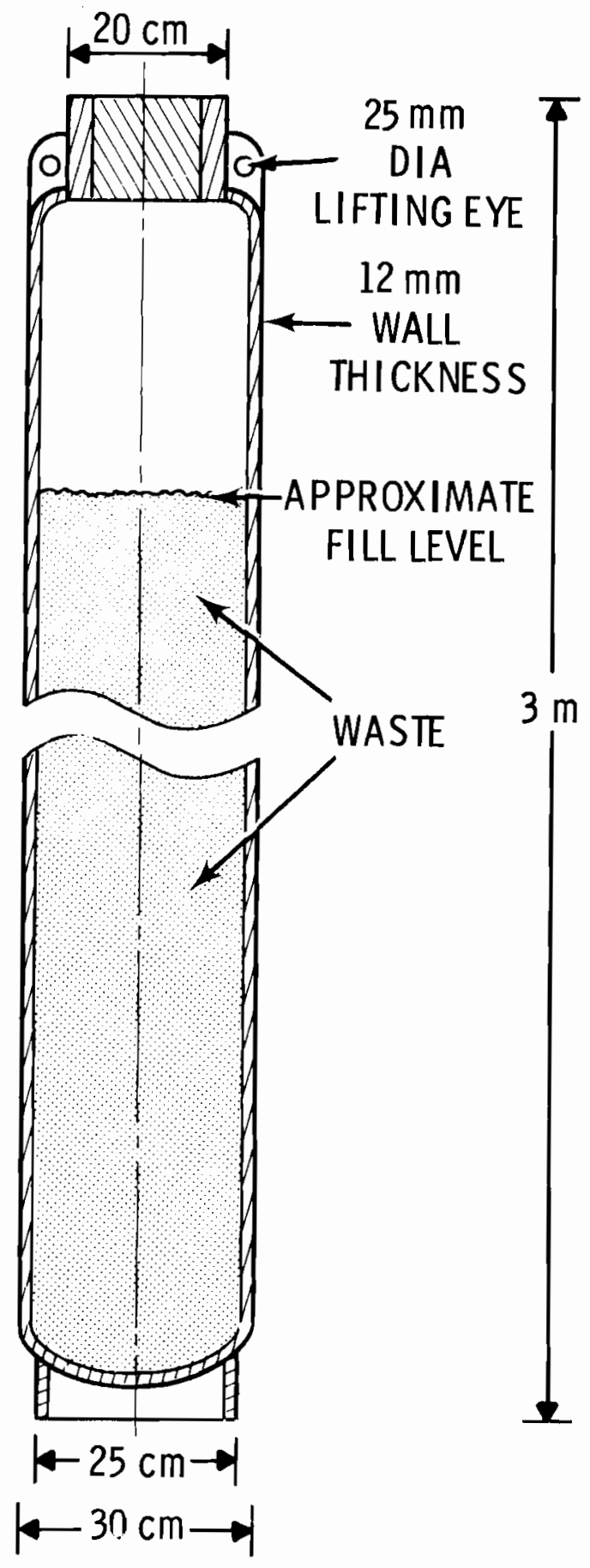

FIGURE 2.1. Geometric Configuration of Reference Waste Canister 
maximize the carrying capacity of the cask while still remaining within clearance and weight restrictions for regular railroad service. Restrictions associated with large size or weight loads were to be avoided for an efficient transportation system. Shipment of SHLW will be a highly centralized operation between a restricted number of fuel reprocessing plants and federal storage facilities. It was assumed that the shipments would be made over main line tracks or branch lines with clearance and weight restrictions similar to those currently in force on main line tracks. The standard railroad clearance outline shown in Figure 2.2 was used to establish maximum cross-sectional dimensions of the cask/railcar system.

The railroad clearance office of Burlington Northern, Inc, in Minneapolis, Minnesota, was contacted to obtain general guidelines and procedures for transportation of heavy loads. The information below was obtained from these contacts:

- the maximum gross weight for a car with four axles is 120 metric tons; gross weight for cars with 6 axles is $50 \%$ higher (180 metric tons).

- flat cars up to $27 \mathrm{~m}$ in length are handled routinely on main lines

- depressed center flat cars are preferred for high density, large weight loads

- the empty weight of a 6-axle depressed center flat car would range between 35 and 45 metric tons.

- cars with gross weights exceeding 180 metric tons are subject to a maximum speed limit of $65 \mathrm{~km}$ per hour on main line tracks if moved in normal train service.

- cars carrying grain and coal are routinely loaded with 90 metric tons of cargo.

- Several depressed center flat car designs are available for carrying high density, large weight cargo.

The following cask/railcar system design criteria was established from this information: 


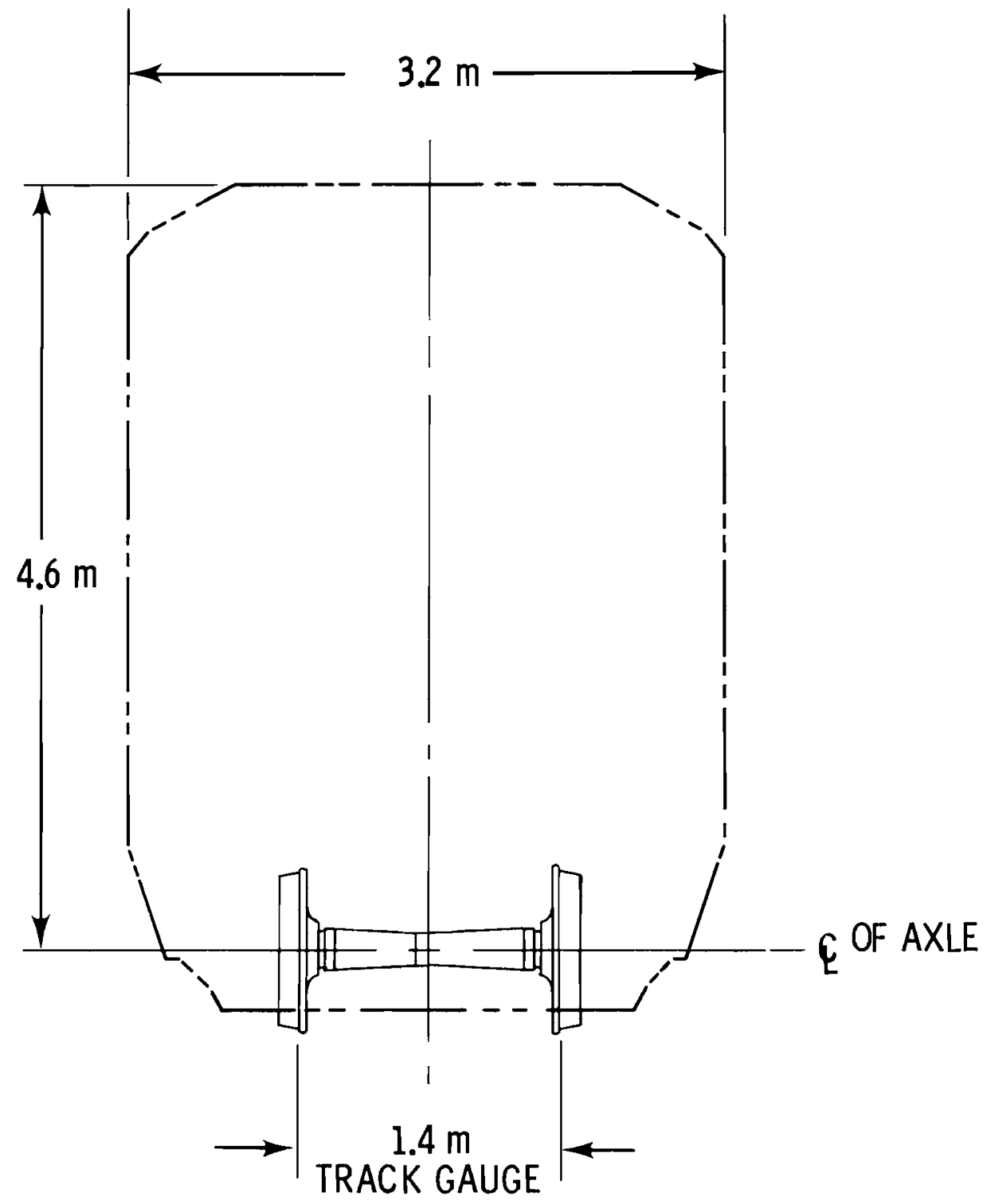

FIGURE 2.2. Standard Railroad Clearance Outline 
- The net weight of the cask should not exceed 140 metric tons. A design target weight of 110 metric tons was selected to provide a margin for future design changes.

- A depressed center flat car should be used.

- Cask systems with gross weights up to 90 metric tons would be carried on flat cars with 4 axles. Cask systems with greater gross weights would utilize flat cars with 6 axles.

- The car design should be similar to flat car designs currently in use.

\subsection{HANDLING AND OPERATING CONSIDERATIONS}

Handling and loading constraints which affect cask design can occur at either end of the transportation cycle (i.e., transfer from storage at the fuel reprocessing piant to the cask or transfer from the cask at the federal repository). Loading and unloading of the cask will be done remotely. Alternative methods of loading and unloading at either end of the transportation cycle which will impact the cask system design are tabulated below:

- removal of the cask from the railcar for loading underwater

- removal of the cask from the railcar for loading or unloading in a dry-we 11

- tilting or rotating the cask up to $90^{\circ}$ while mounted on the railcar to facilitate insertion of the canisters

- removal of the lid without change in position of the cask body for direct insertion of the canisters.

Cask design features to accommodate the constraints at either the fuel reprocessing plant or the federal repository have yet to be determined. It is assumed that the requirements will be similar at each facility. Contacts with representatives of companies that have participated in the design and operation of commercial reprocessing facilities indicated that removal of the cask from the conveyance vehicle for renote loading in a water basin or dry-well would be the most restrictive cask handling procedures from a cask-design standpoint. 
The assumption was therefore made that the cask body would be removable from the flat car for loading or unloading of the canisters.

The cask/railcar system will also be subjected to routine rail transport conditions such as vibration and forces associated with starting and stopping the train and maneuvering around corners and over grades. These factors are primarily a consideration in designing the tiedown system that holds the cask to the railcar. The flat cars used to transport SHLW casks are expected to be a dedicated unit, similar to those presently used for transporting large spent fuel casks. Therefore, the cask tiedowns will be permanent and can take advantage of the frame of the flat car to augment strength. The criteria for restraint of the cask on the flat car by the tiedowns are presented in Table 2.7. These criteria are the same as those used for a currently-licensed 73 metric ton spent fuel cask. 8

\section{TABLE 2.7. Tiedown Design Criteria}

$\begin{array}{lc}\text { Direction of Force } & \text { Restraint (in g's) } \\ \text { horizontal (axial) } & 10 \\ \text { horizontal (lateral) } & 5 \\ \text { vertical } & 2\end{array}$

The " $g$ " levels of restraint shown in the table are primarily intended to accommodate the loadings during normal transportation operations. Force levels during severe accidents can exceed the tiedown criteria and cause the cask to separate from the flat car. These higher forces (or the resultant energy) must be accommodated by an energy absorbing system on the cask body. 


\subsection{CONCEPTUAL SOLIDIFIED HIGH-LEVEL WASTE CASK SYSTEM}

The previous section discussed design constraints for the conceptual cask system. This section describes the conceptual cask/rail car system. Design rationale and supporting calculations are also presented.

\subsection{CASK/RAILCAR DESCRIPTION}

An artist's representation of the conceptual cask/railcar system developed in this study is presented in Figure 3.1. Important cask design parameters are summarized in Table 3.1. The cask shown has a capacity of nine canisters of the reference solidified high-level waste described in Section 2.2. The conceptual cask is cooled by natural convection from the cooling fins on the cask body. The maximum heat removal capability of the cask is $50 \mathrm{kw}$. The loaded cask wighs about 110 metric tons and is shipped on a conventional 6axle depressed-center flat car that has been modified by the permanent installation of the cask tiedown system. The gross shipping weight of the cask and railcar is about 160 metric tons. The conceptual solidified highlevel waste cask/railcar system is similar in many respects to currentlylicensed casks for shipping spent fuel by rail.

Details of the cask structure and internal design features are presented in Figure 3.2. The cask body is $4 \mathrm{~m}$ long with an overall length, including cooling fins, of $4.4 \mathrm{~m}$. The cask cavity is $1.5 \mathrm{~m}$ in diameter and the outside diameter of the cooling fins is $2.5 \mathrm{~m}$. The inner cask cavity contains a solid aluminum magazine to position the waste canisters and transfer the heat from the canisters to the main cask body. Each canister is held in place by a three-part positioner that is pressed against the canister by leaf springs. An aluminum honeycomb impact absorber is placed at each end of the canister when it is loaded into the cask. The cask is designed to be shipped dry (i.e., water is not required in the cask cavity for heat transfer).

The cask body is a series of concentric shells. The inner wall, constructed of $1.9 \mathrm{~cm}$ thick stainless steel, is surrounded by a lead gamma radiation shield $20 \mathrm{~cm}$ thick. The gamma shield is contained by a $5 \mathrm{~cm}$ thick stainless steel structural wall. A $10 \mathrm{~cm}$ thick borated water neutron shield surrounds the outer structural wall. The neutron shield water is divided among four compartments. Each compartment is connected to a $100 \ell$ expansion tank (not 


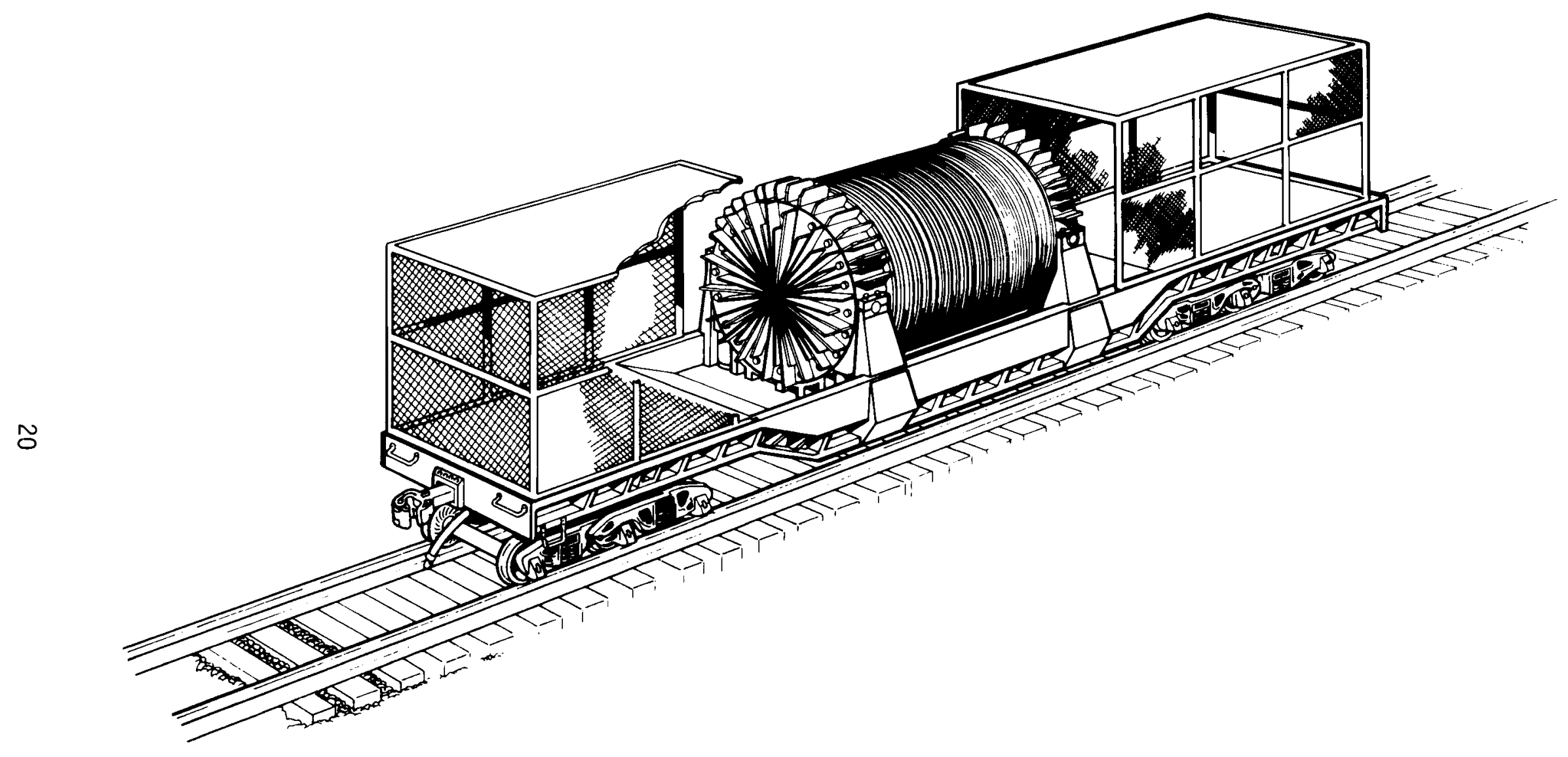

FIGURE 3.1. Conceptual Solidified High-Level Waste Shipping Cask and Railcar (Personnel Shield Shown in Open Position for Loading and Unloading) 
TABLE 3.1. Conceptual SHLW Cask Design Parameters

Dimensions

Overall Length $\quad 4.4 \mathrm{~m}$

Overall Diameter $\quad 2.5 \mathrm{~m}$

Length of Structural Shell $4.0 \mathrm{~m}$

Outside Diameter of Structural Shell $2.3 \mathrm{~m}$

Cavity Diameter $\quad 1.5 \mathrm{~m}$

Cavity Length $\quad 3.3 \mathrm{~m}$

Capacity

9 Canisters of Reference SHLW

Reference SHLW Characteristics

Waste Type

Borosilicate Glass

Age When Shipped

5 Years Since Reprocessing

(6.5 years since reactor discharge)

Canister Dimensions

$30 \mathrm{~cm}$ Diameter $\times 3 \mathrm{~m}$ Length

Heat Removal Capability

$50 \mathrm{kw}$

Heat Removal System

Gamma Radiation Shielding

Cask Wall

Natural Convection from Radial Cooling Fins

Ends

$20 \mathrm{~cm}$ Lead

$12.7 \mathrm{~cm}$ Depleted Uranium

Neutron Radiation Shielding

Cask Wal1

$10 \mathrm{~cm}$ Borated Water

Ends

$7.6 \mathrm{~cm}$ Sol id Hydrogenous Material

Transport Mode

Rai1

Transport Vehicle

Dedicated Depressed Center

Flatcar

Weight

Cask and Contents

110 metric tons

Loaded Cask and Railcar

160 metric tons 


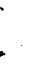




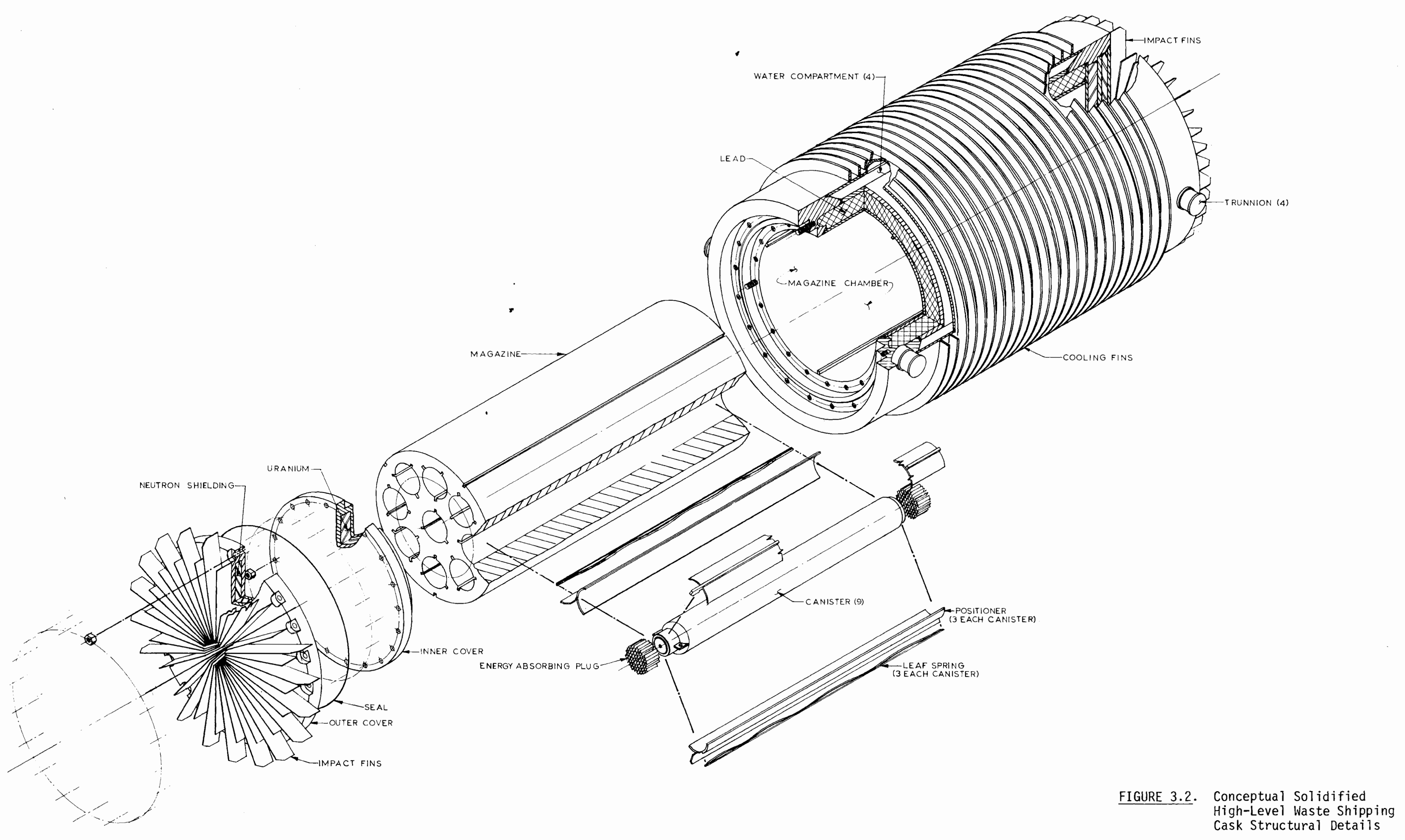




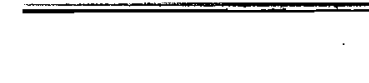


shown in the figures) that permits the water to remain at a pressure of about 1 atmosphere over the maximum range of temperatures expected during normal operation. Each compartment is also supplied with a pressure relief valve that prevents the neutron shield water pressure from exceeding 5 atmospheres. Ethylene glycol is added to the shield water to prevent freezing when the cask is shipped empty. The cask body is completed by a $1.2 \mathrm{~cm}$ thick stainless steel outer wall and a series of radial cooling fins $1.2 \mathrm{~cm}$ thick and $10 \mathrm{~cm}$ high.

The stainless steel cask 1 id is constructed in two pieces. Double lid construction has been used on some large spent fuel casks. This concept provides a stronger closure since more area is available for attaching the head bolts. The inner lid of the conceptual cask contains a $12.7 \mathrm{~cm}$ thick layer of depleted uranium for gamma radiation shielding. Depleted uranium is used to provide additional strength in the lid if the cask is involved in an accident. The outer lid contains a $7.6 \mathrm{~cm}$ thick layer of solid hydrogenous material for neutron shielding. The stainless steel fins on the outer lid function as impact absorbers in an accident. Each lid is attached to the cask body by twenty $5 \mathrm{~cm}$ diameter stainless steel bolts. A metallic o-ring gasket is used to seal the outer lid to the cask body. The cask bottom is not removable, but is otherwise similar to the $1 \mathrm{id}$. Four $18 \mathrm{~cm}$ diameter trunnions are mounted on the cask. The trunnions extend $14 \mathrm{~cm}$ from the cask body and support the cask during handling and shipping.

The cask tiedown and handling systems are shown in Figure 3.3. The tiedown equipment is permanently mounted on the railcar. The tiedowns consist of four massive columns that support the cask during shipment. The trunnions on the cask body rest on the support columns. The cask is clamped in place at each end by a steel semicircular retaining ring $2.5 \mathrm{~cm}$ thick that is bolted to the top of the support columns. Energy-absorbing impact fins are welded to the steel rings. A support pad is located under the front and rear of the cask to provide additional restraint if the cask and tiedown assembly is subjected to large axial accelerations during shipment.

The cask is unloaded from the railcar by removing the retaining rings, lifting the cask with the installed hydraulic jacks so that the forward set of trunnionsclears the support column, and attaching a specially designed 
. 


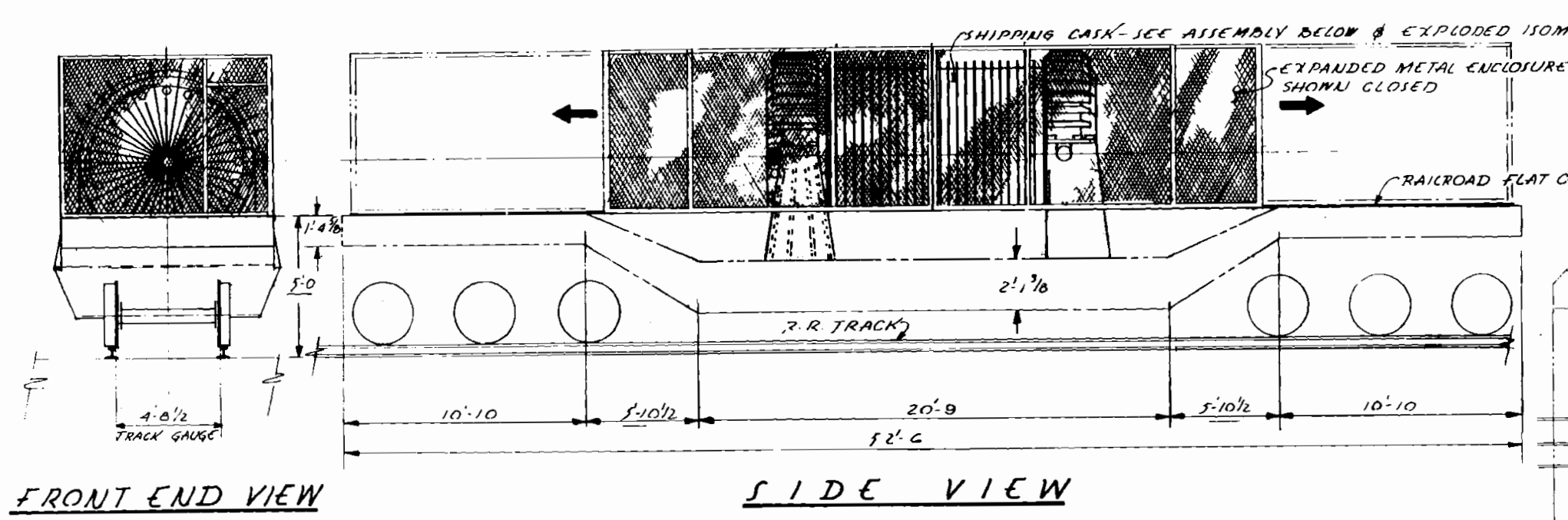

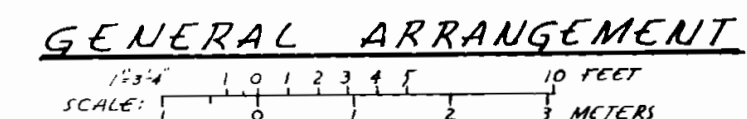
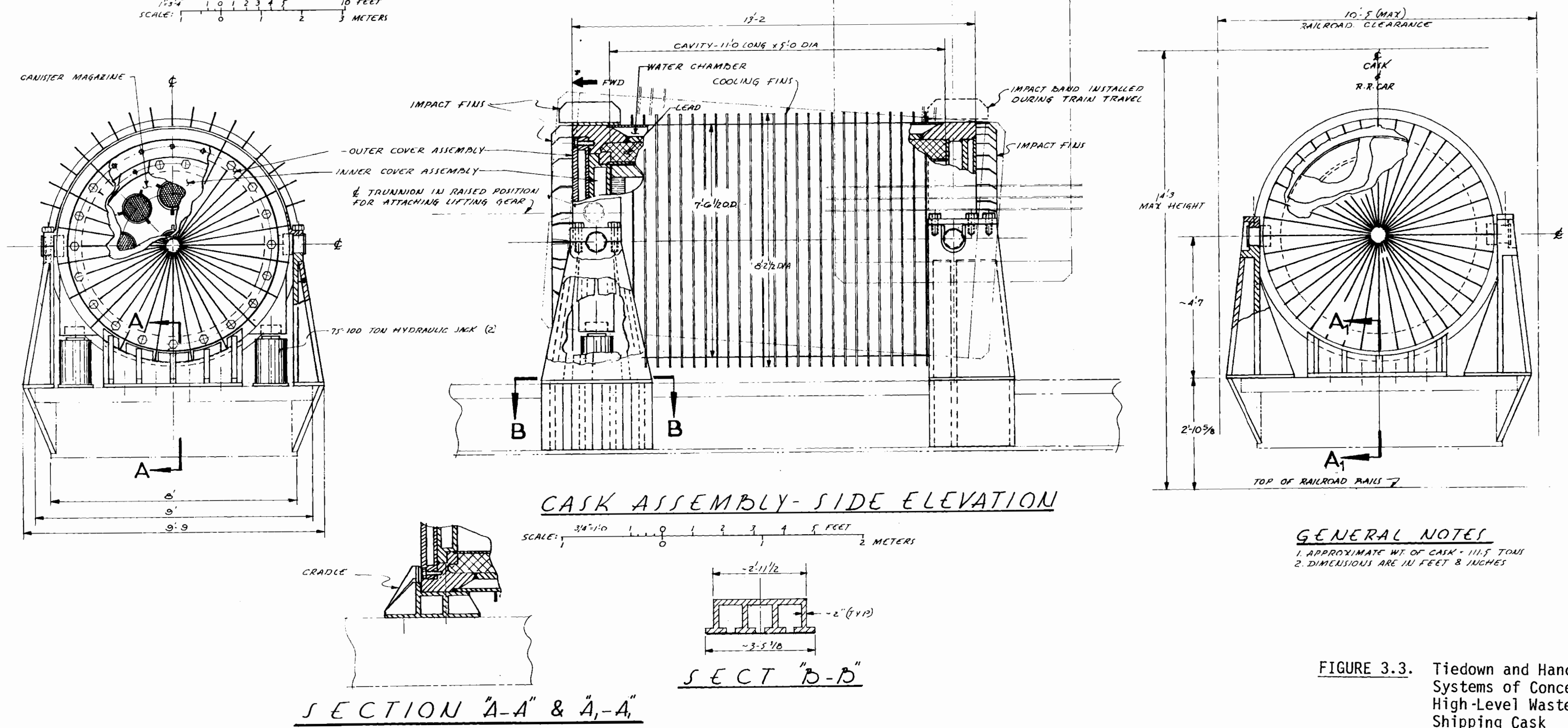

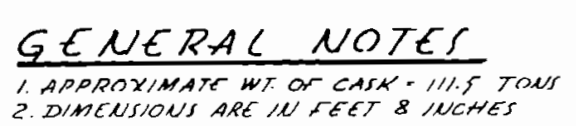

FIGURE 3.3. Tiedown and Handling Systems of Conceptual High-Level Waste Shipping Cask 
, 
lifting cradle suspended from a large crane to the trunnions. The cask rotates about the rear trunnions while it is lifted to the vertical position with the crane. The position of the cask during transport after it has been 1 ifted by the jacks and in the vertical position just prior to removal from the railcar are shown in Figure 3.3.

The depressed center railcar shown in Figures 3.1 and 3.3 is a standard design with some modifications to accommodate the conceptual cask. The deck of the car is steel to facilitate attachment of tiedown equipment and permit easy cleanup of any radioactive contamination that might occur. The support columns and associated bracing and the hydraulic jacks and auxiliary equipment are permanently mounted on the car. An expanded metal cage covers the cask during shipment. This cage keeps debris off the cask and prevents people from contacting the heated outer surface of the cask. The cage is constructed in two pieces that slide back onto the car deck during cask loading and unloading operations.

\subsection{BASES FOR REFERENCE DESIGN}

Much of the cask design is defined by the constraints discussed in Section 2.0. Design alternatives are available for satisfying many of these constraints. The choice among design alternatives is usually dictated by economics. The task of the designer is to satisfy the design constraints in the most cost-effective manner. A detailed economic analysis was beyond the scope of this study, so the choice of design approaches and construction materials is based primarily on historical experience with spent fuel casks. In some instances, the choice was based on simplicity or clarity for the models. The major areas of consideration in developing a SHLW cask design are cask structure, heat dissipation, radiation shielding, and cask mounting 
and handling. The design bases for the conceptual cask design and supporting calculations in each of these areas are presented in this section with details in Appendices B and C.

\subsubsection{Cask Structure}

The primary determinant of cask structural strength requirements are the Type $B$ package accident test criteria presented in Table 2.3. The conceptual design relied on the basic shell configuration used for spent fuel casks that have been shown to meet these test criteria. Preliminary calculations have been made that indicate that the conceptual cask design would survive the puncture test and the $9 \mathrm{~m}$ drop test. These calculations are discussed in Appendix C. Calculations were not made for the crush and immersion tests because it was felt that these tests produce much lower stress levels in the cask than the puncture and $9 \mathrm{~m}$ dro? tests.

The conceptual cask is supplied with energy-absorbing impact fins on the ends and on the retaining rings that hold the cask to the support columns during shipment. These fins are designed to minimize damage in a severe transportation accident. The radial cooling fins would also function as energy absorbers in an accident.

Impact absorbers used on spent fuel casks and other large casks for carrying radioactive materials are generally balsa wood, steel fins, or rolled steel shapes. Fins were used for the conceptual SHLW cask design primarily for the simplicity and resulting clarity in a visual display. Internal impact absorbers fabricated from an aluminum honeycomb material were also added at each end of the SHLW canisters because the canisters are readily adaptable to this type of additional protection. The internal impact absorbers could be added to the system at less cost than providing the same degree of protection externally.

\subsubsection{Heat Dissipation}

Heat transfer is a key element in cask design. A compatible thermal environment must be provided for the SHLW canisters during both normal transit 
and under accident conditions. Heat transfer considerations may also affect the choice of radiation shielding material used in the cask. The capacity of the cask to transfer heat from the canisters to the environment must be adequate to prevent physical changes within the waste during transport. The surface temperature of the canister must be maintained at levels that prevent undesirable metalurgical changes. It must also be demonstrated that the cask can withstand the thermal test for Type B packages and the surface temperature of the cask must permit safe handling during loading and unloading operations.

The following factors were established as guidelines for design of the heat dissipation system:

- a passive heat dissipation system (i.e., no circulating internal or external coolant) is desirable.

- the centerline temperature of the canisters should be maintained below $650^{\circ} \mathrm{C}$.

- the surface temperature of the canisters should be kept below $425^{\circ} \mathrm{C}$.

- the temperature in the lead shielding should remain well below the melting points of $330^{\circ} \mathrm{C}$.

- the surface temperature of the cask should remain below $80^{\circ} \mathrm{C}$ for personnel safety.

- the cask must not release any of its contents when exposed to an $800^{\circ} \mathrm{C}$ fire for 30 minutes.

The design approach to develop an effective passive heat dissipation system was to minimize all air gaps within the cask. The first problem to overcome was how to avoid asymmetric heat transfer due to the canisters being inserted in an oversize hole in the aluminum magazine in the center cavity. This was minimized by providing a spring-loaded three-piece positioner around each canister as shown in Figure 3.2. The aluminum magazine was designed such that differential thermal expansions would minimize the gap between the magazine and the inner wall of the cask shell as the 
temperature rose. Cooling fins were provided on all outside surfaces to facilitate heat transfer.

A thermal analysis of the conceptual cask under normal operating conditions and postulated accident conditions was performed to assess the performance of the conceptual design relative to the guidelines listed above. The thermal analysis was based on a total heat generation rate of $50 \mathrm{kw}$ (about $5 \mathrm{kw}$ per canister) for nine reference SHLU canisters. Details of this analysis are presented in Appendix B. Two cases were analyzed: 1) a steady state analysis to determine temperatures at key positions in the cask during normal operation, and 2) a transient analysis to determine temperatures in the cask as a function of time if the cask were exposed to a $1000^{\circ} \mathrm{C}$ fire for one hour. Results of these calculations are summarized in Table 3.2 .

The steadv-state analysis was performed for an ambient air temperature of $50^{\circ} \mathrm{C}$. The analysis shows that the guidelines for waste centerline temperature, canister surface temperature, and lead shielding temperature were easily met by the conceptual design if gans between materials in the shell are kept below $1.5 \mathrm{~mm}$. The conceptual design specifies contacting surfaces between the layers in the cask she11. Quality control procedures during cask construction would ensure that no significant gaps are present. The analysis also shows that the cask surface temperature during normal operations will general1y by $15-25^{\circ} \mathrm{C}$ higher than the guideline of $80^{\circ} \mathrm{C}$. This condition is also present in many spent fuel casks currently in use. This necessitates installation of the screen shown in Figures 3.1 and 3.3 to keep personnel away from the hot surface of the cask.

The transient thermal analysis showed that the SHLW would maintain its containment integrity during exposure to a $1000^{\circ} \mathrm{C}$ fire for one hour. The analysis assumed that the neutron shield water would be released through the pressure release device soon after the fire began. Because the waste has a relatively low heat generation rate and the cask body has a large heat capacity, the temperature of the waste does not change significantly during exposure to a $1000^{\circ} \mathrm{C}$ fire for one hour. Some 
melting of the outer layers of the lead shield may occur at the end of the one-hour fire, but this would not significantly affect the radiation dose rate at the surface of the cask. The analysis indicates that the conceptual cask would remain undamaged during the thermal test required by NRC and DOT regulations $\left(800^{\circ} \mathrm{C}\right.$ fire for 30 minutes $)$.

TABLE 3.2. Results of Thermal Analysis of Conceptual Cask Design

\begin{tabular}{|c|c|c|c|c|}
\hline \multirow[b]{2}{*}{$\begin{array}{l}\text { Location Within } \\
\text { Cask }\end{array}$} & \multirow[b]{2}{*}{$\begin{array}{l}\text { Steady State } \\
\text { Temperature }(\mathrm{a})\left({ }^{\circ} \mathrm{C}\right)\end{array}$} & \multicolumn{2}{|c|}{$\begin{array}{c}\text { Temperature }\left({ }^{\circ} \mathrm{C}\right) \text { During } \\
\text { to } 1000^{\circ} \mathrm{Fire}\end{array}$} & \multirow{2}{*}{$\begin{array}{l}\text { Exposure } \\
60 \mathrm{min!}(\mathrm{b})\end{array}$} \\
\hline & & $20 \min (b)$ & $40 \min (\mathrm{b})$ & \\
\hline Center of $\operatorname{SHLW}^{(c)}$ & 450 & 450 & 450 & 450 \\
\hline Canister Surface ${ }^{(c)}$ & 415 & 415 & 415 & 415 \\
\hline Lead Shielding & 190 & 200 & 240 & 305 \\
\hline Neutron Shield ${ }^{(d)}$ & 125 & -- & -- & -- \\
\hline Cask Surface & 105 & 1000 & 1000 & 1000 \\
\hline $\begin{array}{l}\text { (a) Ambient air } \\
\text { (b) Time after } \\
\text { (c) Hottest can } \\
\text { (d) The neutron } \\
\text { relief devi }\end{array}$ & $\begin{array}{l}\text { perature is } 50^{\circ} \mathrm{C} \\
t \text { of fire } \\
r \\
\text { eld is assumed to } \\
n \text { an extended fire }\end{array}$ & d & n & \\
\hline
\end{tabular}

\subsubsection{Shielding}

Gamma ray and neutron shielding is required in the conceptual cask to meet the radiation safety requirements of NRC and DOT requlations (see Section 2.1). The shielding requirements associated with a SHLW shipping cask will not decline significantly with time for the first 10 years following separation of the waste from the fuel. Only a reduction of about $20 \%$ in the 
thickness of the gamma ray shielding material is gained for 10-year old waste relative to waste that has just been separated. Detailed shielding calculations were therefore not made for the conceptual cask design. A parametric study by Oak Ridge National Laboratory of casks for transporting solid radioactive wastes ${ }^{(7)}$ was used as the basis for selecting shielding thicknesses. Some small corrections were made to reflect differences between the reference waste used in this study and the Oak Ridge study.

Typical shielding materials used in large shipping casks are lead, iron and depleted uranium. The comparative properties of these materials are shown in Table 3.3. The choice of shielding material for a particular cask depends on a variety of factors including:

- permissible cask weight and size

- the amount of shielding required

- cost of materials

- heat transfer requirements

- structural strength requirements

- requiired performance under accident conditions

- manufacturing costs

Because of the many factors that must be considered, the choice of a shielding material usually involves tradeoffs with.other cask design parameters. For example, data in Table 3.3 show that lead and uranium shielding produce about the same attenuation of $0.63 \mathrm{MeV}$ gamma rays for a given mass of shielding while an iron shield with an equivalent attenuation factor would weigh about one third more. Uranium and iron have significantly higher yield strengths than lead. The thermal conductivity of iron is better than lead, which in turn, is better than uranium. The low melting point of lead is a consideration in accident situations that involve fire, but provides advantages during construction since it can be readily poured into an annulus in the cask shell.

Detailed economic, engineering and safety analysis studies are required to select the optimum shielding material for a particular cask. Such studies are beyond the scope of efforts performed for a conceptual 
design. The shielding material selections were based on past experience with spent fuel cask designs, parametric studies such as the Oak Ridge work, and engineering judgment of a reasonable balance between the many competing factors.

TABLE 3.3. Typical Properties of Shielding Materials

\begin{tabular}{|c|c|c|c|}
\hline & Lead & $\begin{array}{r}\text { Depleted } \\
\text { Uranium } \\
\end{array}$ & $\begin{array}{c}\text { Mild Steel } \\
\text { and Iron }\end{array}$ \\
\hline Density $\left(\mathrm{gm} / \mathrm{cm}^{3}\right)$ & 11.3 & 19.1 & 7.9 \\
\hline Melting Point $\left({ }^{\circ} \mathrm{C}\right)$ & 330 & 1130 & 1540 \\
\hline Yield Strength $\left(\frac{\text { newtons }}{\mathrm{m}^{2}} \times 10^{6}\right)$ & $8.1-9.5$ & $170-310$ & $410-860$ \\
\hline $\begin{array}{l}\text { Modulus of Elasticity } \\
\left.\qquad \frac{\text { newtons }}{m^{2}} \times 10^{9}\right)\end{array}$ & 14 & 165 & 200 \\
\hline $\begin{array}{l}\text { Thermal Expansion } \\
\qquad\left(\mathrm{cm} / \mathrm{cm}-{ }^{\circ} \mathrm{C} \times 10^{-6}\right)\end{array}$ & 29 & $6.8-15$ & 11.7 \\
\hline Specific Heat $\left(\mathrm{cal} / \mathrm{g}-{ }^{\circ} \mathrm{C}\right)$ & 0.031 & 0.028 & 0.11 \\
\hline $\begin{array}{l}\text { Thermal Conductivity } \\
\qquad\left(w / m-{ }^{\circ} K\right)\end{array}$ & 34.4 & 24.2 & 45.8 \\
\hline $\begin{array}{l}\text { Tenth Value Thickness (cm) } \\
\qquad\left(E_{\gamma}=.63 \mathrm{MeV}\right)(\mathrm{a})\end{array}$ & 2 & 1.1 & 3.4 \\
\hline Mass of Equivalent Shielding(b) & 22.3 & 21.0 & 26.9 \\
\hline
\end{tabular}
(a) Thickness of material required to attenuate a source of $.63 \mathrm{MeV}$ gamma rays by a factor of 10 .
(b) Mass of a piece of shielding $1 \mathrm{~cm} \times 1 \mathrm{~cm} \times$ tenth value thickness 
Lead was selected for the gamma shield material in the shell of the cask. Depleted uranium was selected as a gamma shield material in the closed end and lid of the cask body. Lead was selected for the main body because 1) it is generally the least expensive gamma shield material, 2) the temperature during operation was well below the melting point $\left.\left(330^{\circ} \mathrm{C}\right), 3\right)$ the thermal analvsis showed that significant melting with the resultant loss of shielding did not occur during exposure to a $1 / 2$-hour fire at $800^{\circ} \mathrm{C}$, and 4) the strength of the shielding material was not critical to cask integrity. Depleted uranium was selected for the closed end and lid of the cask body because of its inherently greater strength and resultant resistance to axial impact or puncture forces. The use of uranium in the ends of the cask body has the additional advantage of serving as a neutron reflector.

The parametric study of SHL!! shipping casks (Reference 7) found that additional neutron shielding was necessary in the shell of the cask. A layer of water up to $12.7 \mathrm{~cm}$ thick containing $1 \%$ boron was found sufficient if located outside the gamma shield for a range of SHLW compositions. Based on the calculations in Reference 7 , thickness of water required for 9 reference canisters in a large lead-shielded cask was estimated to be $10 \mathrm{~cm}$.

\subsubsection{Cask Handling and Tiedown Systems}

The primary consideration in the design of the cask handling systems is efficiency of loading and unloading operations. An efficient cask handling system reduces cask turnaround times resulting in better cask utilization and reduction of transportation costs. An efficient cask handling system will also minimize radiation exposure to personnel loading the cask on the railcar and removing it from the car at its destination. The cask handiing system used for the conceptual cask design is based on systems currently used for spent fuel casks shipped by rail.

The cask tiedown system is also an adaptation of the systems used for spent fuel casks shipped by rail. The nedestals that support the cask during shipment and during loading and unloading operations were designed to 
withstand the stress levels presented in Section 2.4. Calculations have been made to show that the pedestal designs presented meet these design criteria. Results of these calculations are presented in Appendix C, along with a structural analysis of the lifting trunnions. 



\subsection{ALTERNATE CONSIDERATIONS IN CASK SYSTEM DESIGN}

The conceptual cask system described in the previous section is based on a reference SHLW canister with fixed physical characteristics. This section discusses both the flexibility and limitations of the system to accommodate SHLW canisters with different configurations and properties. The SHLW characteristics identified as most influential on cask design are the heat generation rate and the gamma radiation level. These characteristics establish the heat dissipation and shielding requirements.

The heat generation rate in the SHLW is directly related to the age and composition of the waste and declines significantly after 4 to 6 years. Thus, a cask system designed to transport SHLW of less age, but similar in all other respects, requires a greatly enhanced capability to dissipate heat. Large spent fuel casks for railroad transport, such as the IF-300 (manufactured by General Electric) ${ }^{(8)}$ or the NI-10/24 (manufactured by NL Industries), ${ }^{(9)}$ have the capability to dissipate 90 kilowatts or more of internally-generated heat. These casks require an active coolant system with circulating internal or external fluid.

The conceptual SHLW cask system described in this document can dissipate up to 50 kilowatts of decay heat with a passive heat dissipation system. If the age of the waste were less than approximately three years, an active system would be required. Higher thermal flux due to either younger waste or a stronger composition might also require the use of materials other than lead as a gamma shielding material because operating temperatures in the shield for a passive heat dissipation system would approach the melting temperature of lead.

Figure 4.1 presents a summary of calculated temperatures at several points in the cask as a function of waste age. The figure also shows the effect on temperatures in the cask of varying the number of reference canisters shipped at one time. The figures show that reducing the age of the waste would probably require shipment of fewer canisters to maintain cask 


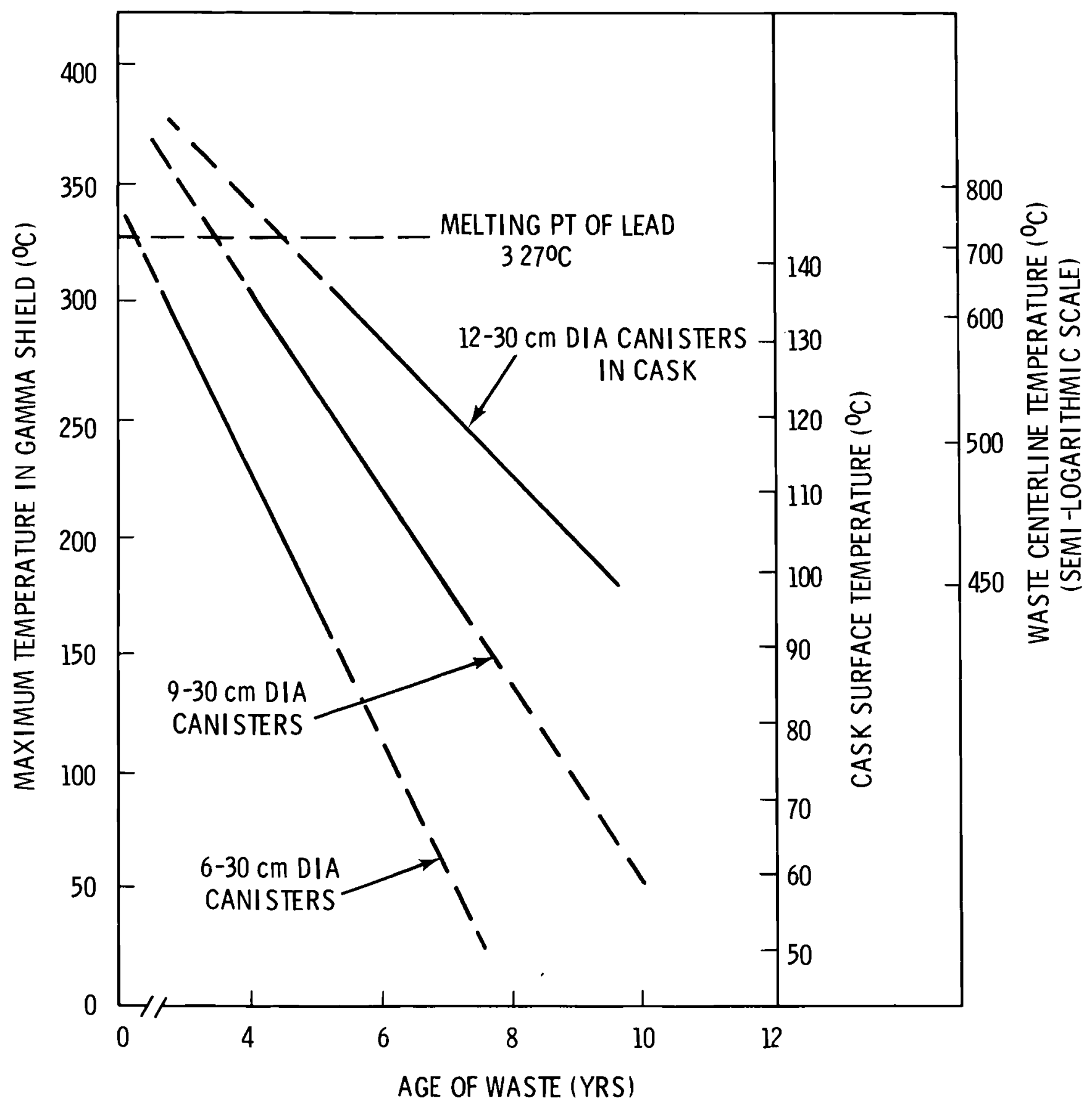

FIGURE 4.1. Temperature at Selected Points Throughout the Cask as a Function of Waste Age 
temperatures at satisfactory levels. A curve for twelve reference canisters is also shown for comparison, although the conceptual cask would not be able to hold this many canisters.

Other factors can also significantly impact cask design, depending upon the final values chosen, including:

- the volume occupied by the canister assembly per unit volume of waste

- the length to diameter ratio of the canisters

- the canister diameter

The volume of the canister assembly per unit volume of SHLW can change significantiy from the reference value used if a protective overpack is added to the canister before shipment or if the HLLW is diluted with Targer quantities of inert material during solidification. Steel protective overpacks could add up to $15 \mathrm{~cm}$ to the diameter of a $30-\mathrm{cm}$ diameter reference canister and would decrease the allowable heat flux from the canister. Overpacks adding more than two to five $\mathrm{cm}$ to the canister diameter would significantly reduce the capacity of a multiple-canister cask due to both greater shielding weight (the shielding layer would be at a greater diameter) and constraints on the overall diameter to comply with railroad clearances.

The length to diameter ratio of the canisters determines the shape of the cask body and the orientation in which the canisters are carried. Slender canisters with length to diameter ratios near ten dictate that the cask body be circular in cross section. If the overall canister length is under about five feet, the canisters can be conveyed either horizontally or in an upright position. Lengths approaching ten feet will require the axis of casks to be horizontal due to transportation clearance restrictions.

The conceptual cask design is based on a reference SHLW canister diameter of $30 \mathrm{~cm}$. Canister diameters ranging from $15 \mathrm{~cm}$ to $60 \mathrm{~cm}$ are being considered in HLLW solidification studies. The conceptual cask could be used to transport waste canisters of different diameters from the reference canister by fabricating a new aluminum magazine and inserting it in the cask cavity. The effect of different canister diameters on the carrying capacity 
of the conceptual cask is shown in Figure 4.2. The loading patterns are based on the maximum number of canisters that can be placed in the $150-\mathrm{cm}$ diameter cavity while maintaining a clearance circle $10 \mathrm{~cm}$ in diameter greater than the canister. The clearance circle allows room for the canister positioning devices and ensures that the wall thickness of the aluminum magazine is adequate to support the canisters and the positioners.

The effect of alternative canister diameters on the cask design parameters is shown in Table 4.1. Larger canister diameters produce the most efficient shipping system because more waste can be transported per shipment and loading and unloading operations would be simplified with fewer canisters in each shipment. Further analysis would be required to determine if the conceptual cask had sufficient shielding and heat removal capacity to accommodate three $60-\mathrm{cm}$ diameter canisters of 5-year-old waste, but this canister size would be favored on the basis of transportation system efficiency.

\section{TABLE 4.1. Comparison of Alternative Canister Sizes}

\begin{tabular}{cccc}
$\begin{array}{l}\text { Canister } \\
\text { Diameter }(\mathrm{cm})\end{array}$ & $\begin{array}{c}\text { Maximum Number } \\
\text { of Canisters in } \\
\text { Reference Cask }\end{array}$ & $\begin{array}{c}\text { Waste Volume } \\
\text { Per } \\
\text { Shinment }\left(\mathrm{m}^{3}\right)\end{array}$ & $\begin{array}{c}\text { Heat Generatjon } \\
\text { Rate (kw) }\end{array}$ \\
\cline { 1 - 2 } 30 & 9 & 1.58 & 46 \\
45 & 4 & 1.58 & 46 \\
60 & 3 & 2.10 & 63 \\
23 & 15 & 1.48 & 44 \\
15 & 27 & 1.18 & 36
\end{tabular}
(a) $80 \%$ of theoretical canister volume
(b) Based on 5-year-old reference waste 


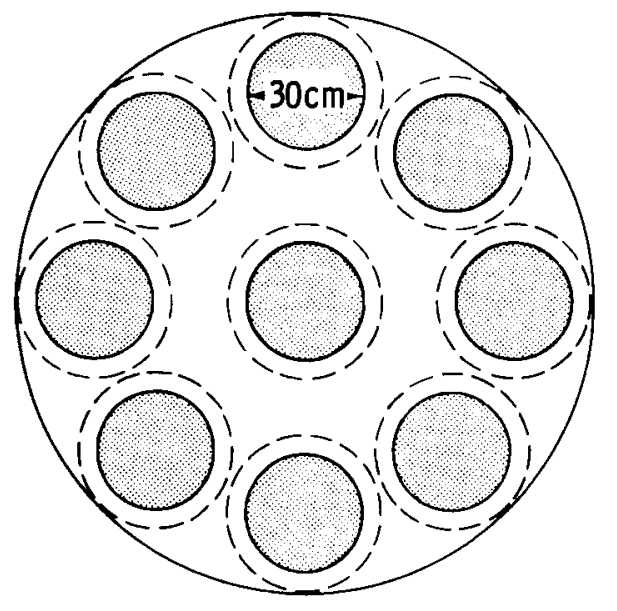

(a)

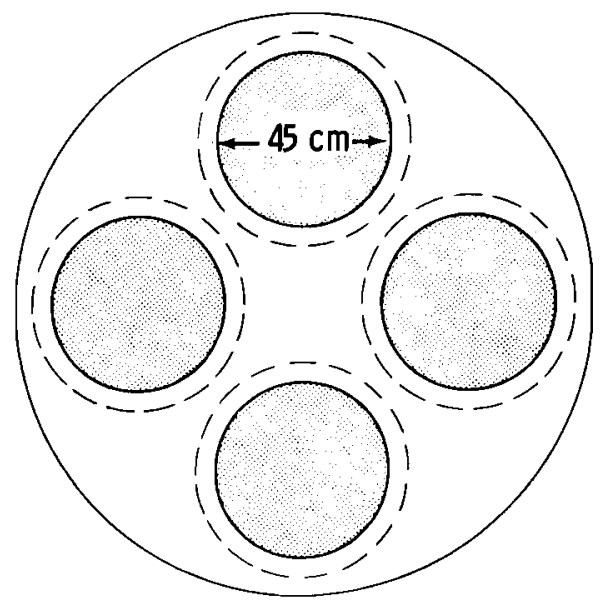

(b)

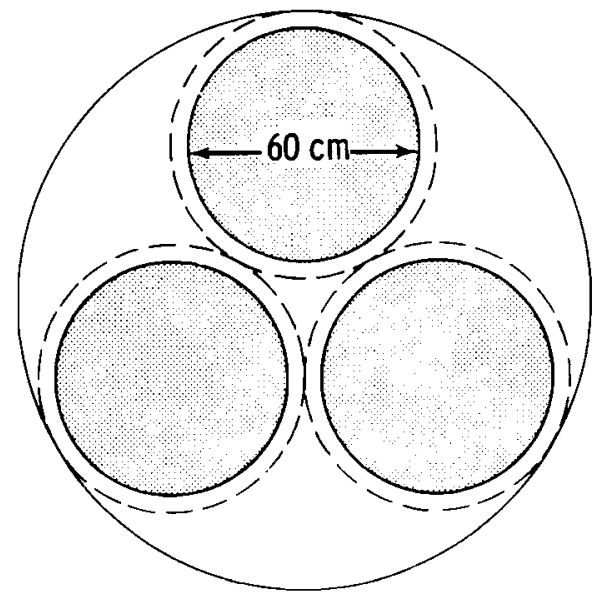

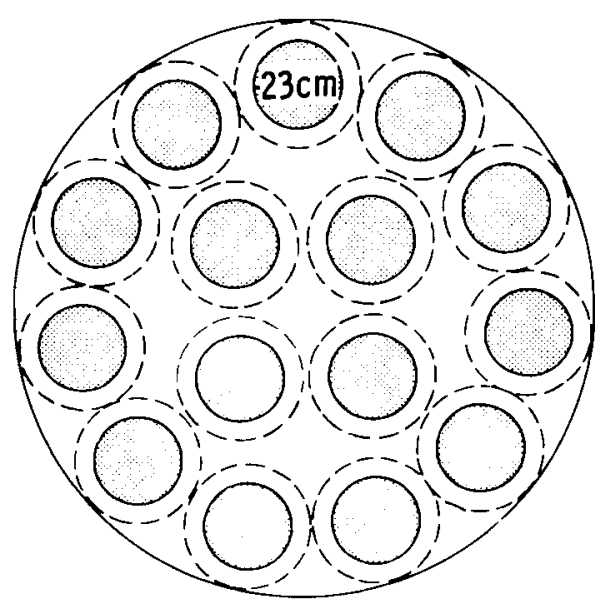

(d)

(c)

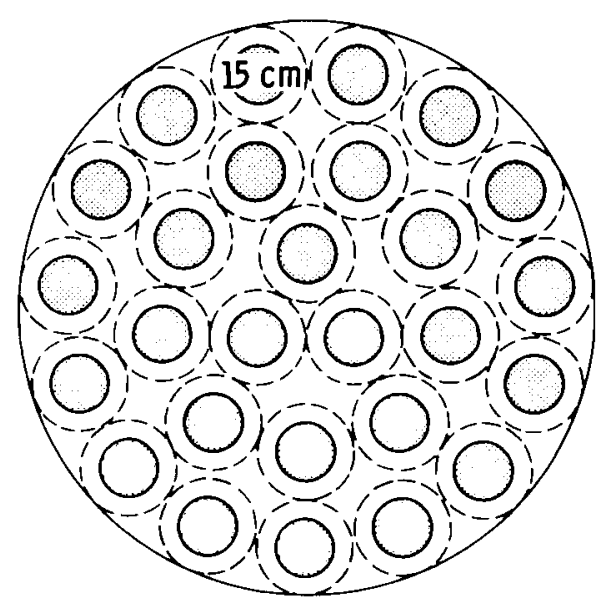

(e)

FIGURE 4.2. Loading Configurations for Canisters of Various Diameters in a $1.5 \mathrm{~m}$ Diameter Inner Cavity 


\section{REFERENCES}

1. Title 49, U.S. Code of Federal Regulations, Part 173.39.2e (2).

2. Title 49, U.S. Code of Federal Regulations, Part 173.393j.

3. Title 49, U.S. Code of Federal Regulations, Part 173.398b (2).

4. R. E. Rhoads, An Overview of Transportation in the Nuclear Fuel Cycle (BNWL-2066), Battelle Pacific Northwest Laboratories, Richland, WA, May, 1977, Appendix A.

5. J. L. McElroy, et. al., "High-Level Liquid Waste Solidification," in Alternatives for Managing Wastes from Reactors and Post-Fission Operations in the LWR Fuel Cycle (ERDA-76-43, Vol. 2), U.S. Energy Research and Development Administration, Washington, D.C., May, 1976, pp. 6.1-6.99.

6. H. J. Bell, ORIGEN--The ORNL Isotope Generation and Depletion Code (ORNL-4628), Oak Ridge National Laboratories, Oak Ridge, TN, May, 1973.

7. J. J. Perona and J. 0. Blomeke, A Parametric Study of Shipping Casks for Solid Radioactive Wastes. (ORNL-TM-3651), Oak Ridge National Laboratory, Oak Ridge, TN, February, 1972.

8. IF-300 Shipping Cask Design and Analysis Report, (NED0-10084-1), Nuclear Fuel Department, Genera 1 Electric Company, San Jose, CA, February, 1973.

9. C. E. Williams, et. al., "Design and Licensing Considerations of the NLI/10/24 Rail Transportation System for Shipping Spent Nuclear Fuel," Proceedings of the 4th International Symposium on Packaging and Transportation of Radioactive Materials. (CONF-740901), Miami Beach, Florida, September 22-27, 1974, pp. 150-163. 


\section{APPENDIX A - Description of Cask Models}

The conceptual SHLW cask design described in this report has been used as the basis for fabricating models for use at technical meetings and in public information displays. Two models have been developed - 1) a $1 / 10$ scale model that is cut away to show the cask internals, and 2) an HO gauge (1/87 scale) model of the cask/railcar system during transportation. A photograph of the $\mathrm{HO}$ gauge cask and railcar is presented in Figure A.l. A photograph of the $1 / 10$ scale model is presented in Figure A.2. An explanatory poster and houndout to accompany the models have also been prepared. These are presented in Figures A.3 and A.4. Further information on the models and accompanying graphics can be obtained from the report authors or from the:

Transportation Branch

Division of Environmental Control Technology

U.S. Department of Energy

Washington, D.C. 
के

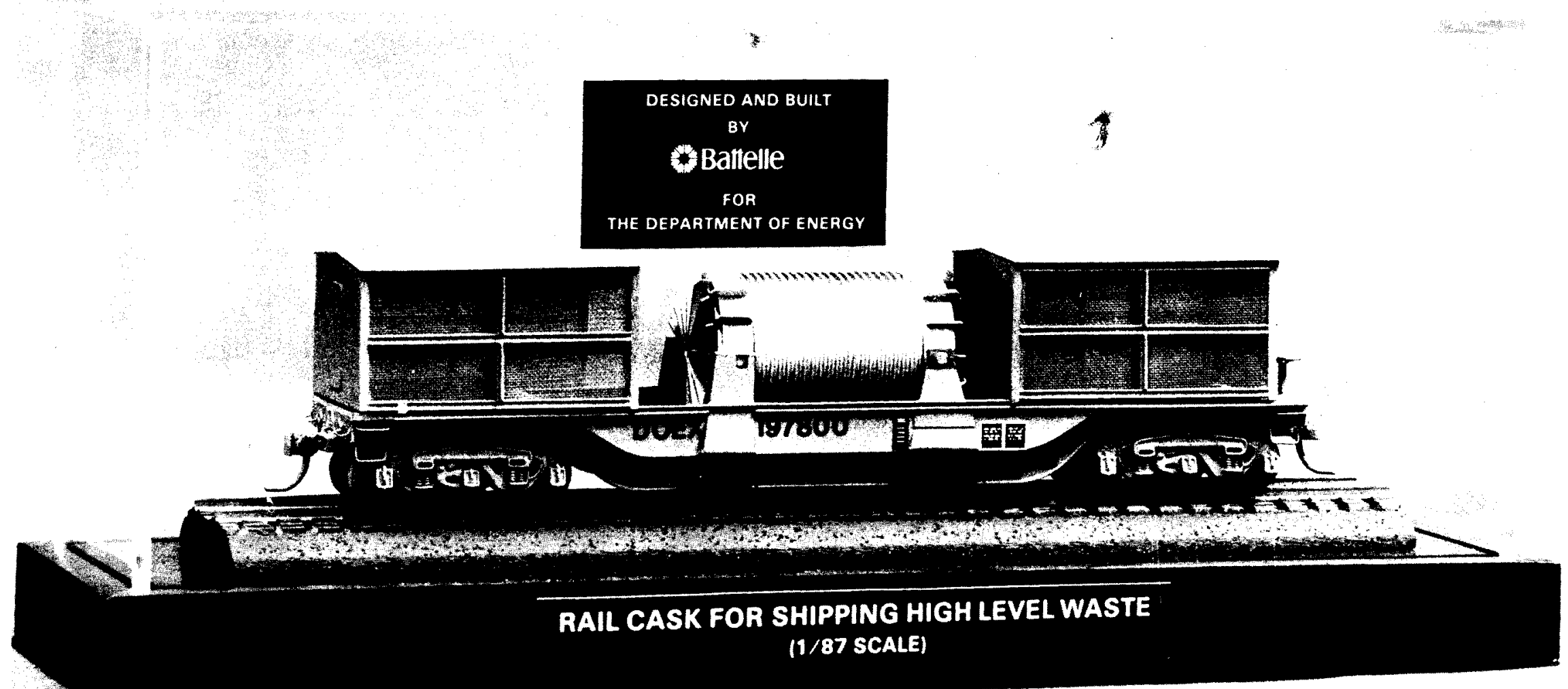

FIGURE A.1. Photograph of HO Gauge (1/87) Scale Model of SHLW Cask and Railcar System 


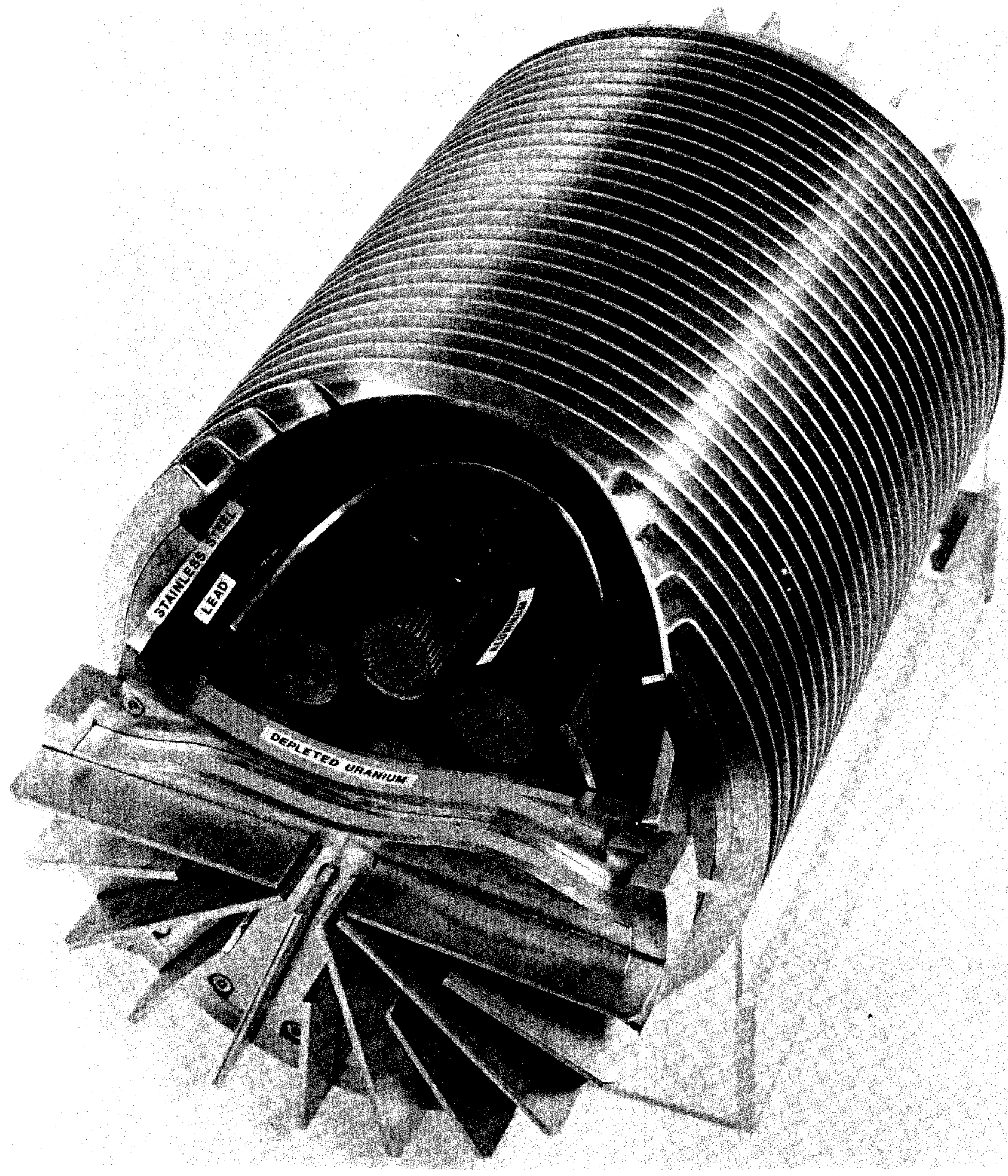

FIGURE A.2. Photograph of the $1 / 10$ Scale Model of the SHLW Rail Cask 


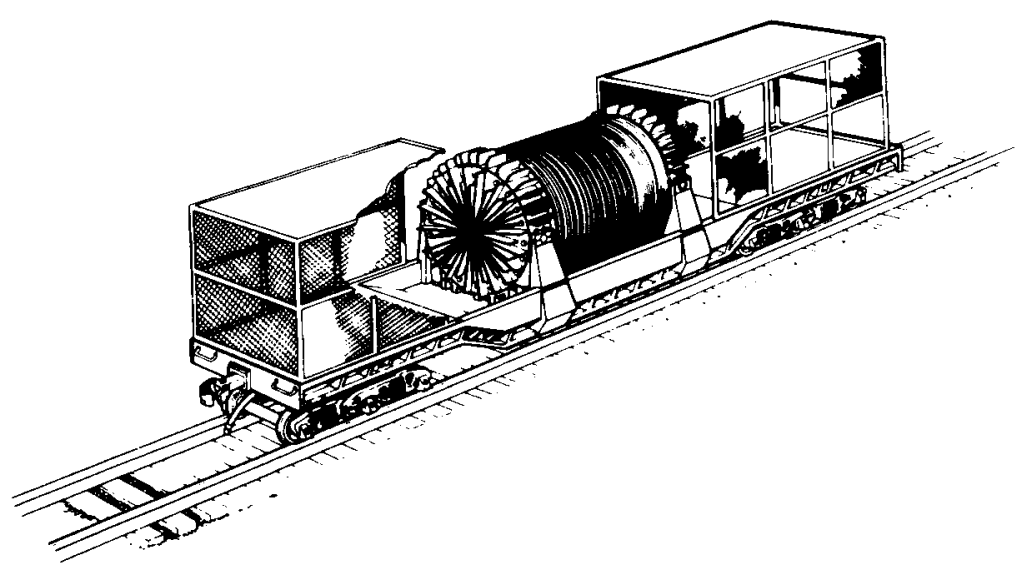

SHIPPING CASK PARAMETERS:

- LENGTH OF CASK (NOT INCLUDING FINS)

- OUTSIDE DIAMETER OF CASK (NOT INCLUDING FINS)

- DIAMETER OF INNER CAVITY
4 METERS
(13.2 FEET)

2 METERS

(6.8 FEET)

1.5 METERS

(5 FEET)

This scale model is representative of shipping casks that will transport high-level solid waste from nuclear fuel reprocessing plants to waste storage facilities. The high-level waste contains radioactive fission products removed during reprocessing of irradiated reactor fuel. The quantity of high-level waste carried by the cask will be about that resulting from one year's operation of a typical modern power reactor. It is also roughly equivalent to the high-level waste resulting from one year's electrical generation by nuclear power for about a half million people.

- CASK WEIGHT

- maximum internal HEAT LOAD

- capacity

- total weight of CANISTERS
100 METRIC TONS (220,000 POUNDS)

50 KILOWATTS LABOUT THE HEAT OUTPUT OF A LARGE HOME FURNACE)

9 CANISTERS, EACH 3 METERS (10 FEET) LONG AND $30 \mathrm{~cm}$ (1 FOOT) DIAMETER

7.5 METRIC TONS (17,000 POUNDS) 


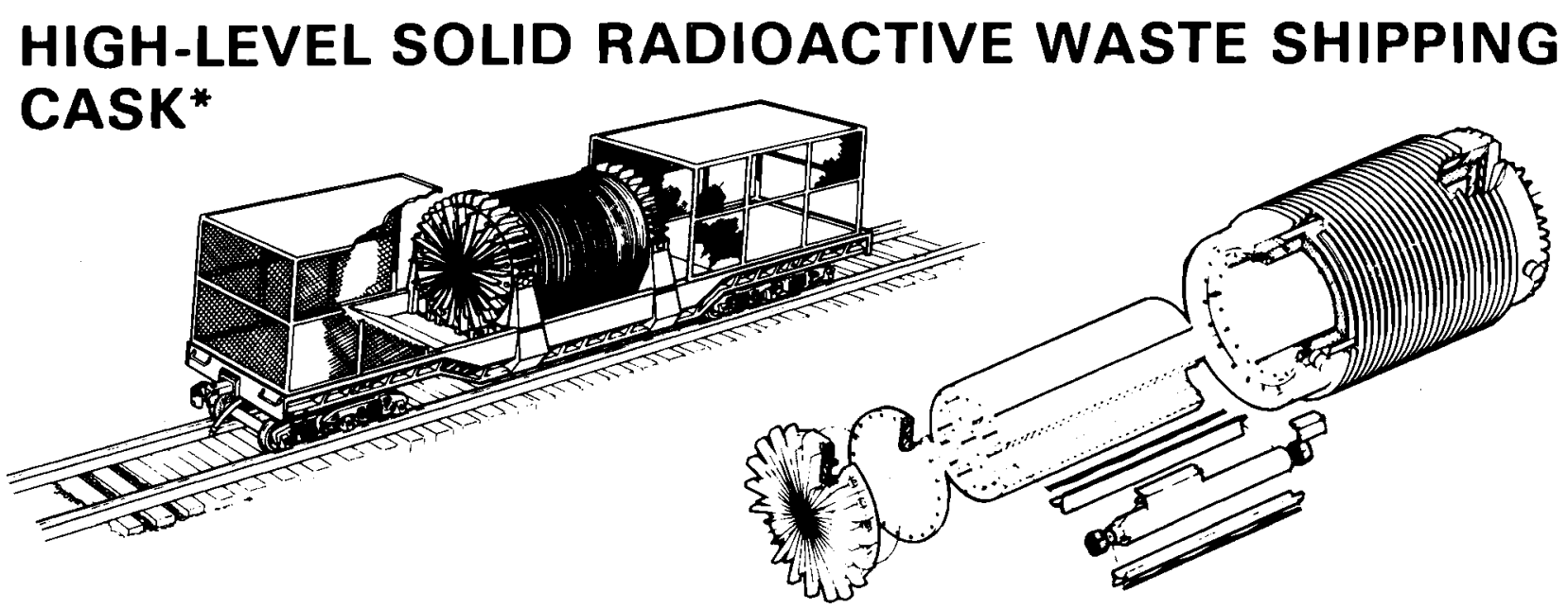

This scale model of a shipping cask and rail car is representative of the system that will be used to transport high-level solid waste between nuclear fuel reprocessing plants and waste storage facilities. The cask carries approximately the amount of high-level radioactive waste 11.3 metric tons or 2800 pounds) removed in reprocessing the spent fuel from one year's operation of a modern (one billion watts electrical output) power reactor. The spent fuel from which the high-level waste is removed will have generated enough electricity to have supplied the average annual electrical needs of more than a half million people.

High-level waste shipping casks will look very similar to the shipping casks presently used to ship spent fuel. The primary reason for developing a cask specifically for high-level solid waste transportation is to reduce shipment costs through selection of a design which maximizes the quantity of waste that can be safely carried. The technology to safely transport these materials has already been demonstrated.

The cask will carry nine canisters of high-level solid waste 30 centimeters (one foot) in diameter and 3 meters (10 feet) long. The length of the cask (excluding fins) is four meters (13.2 feet) and the diameter of the thick structural steel shell is two meters (6.8 feet). The inner cavity diameter is $\mathbf{1 . 5}$ meters (5 feet) and the length is 4.3 meters (11 feet). The canisters are positioned in an aluminum insert that slips into the inner cavity.

Fins on the outside of the cask aid in removal of the heat generated by the waste and also provide an additional degree of protection in case of an accident. The cask can dissipate up to $\mathbf{5 0}$ kilowatts of internally-generated heat. The cask is surrounded by a rectangular cage-like structure to prevent people from touching the hot surface. The cask and rail car require no special attention to ensure safety during shipment.

The cask and its contents will weigh approximately 110 metric tons $(240,000$ pounds) which is about the same weight as a railroad locomotive. More than one-half of the cask weight is shielding material which maintains external radiation levels within Federal regulations. The density and structural features of the cask create an inherently high resistance to damage in rail accidents.

\section{ADDITIONAL INFORMATION}

"Everything You Always Wanted to Know About Shipping High-Level Nuclear Wastes" (DOE/EV-0003) available at a small cost from the superintendent of Documents,

U.S. Government Printing Office, Washington D.C. 20402.

\footnotetext{
*Conceptual design prepared by Pacific Northwest Laboratory for the Department of Energy.
} 


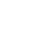




\section{APPENDIX B - Thermal Analys is of Conceptual Cask}

One-dimensional radial steady-state and transient thermal analyses of the conceptual cask were performed using the HEATING 4 heat conduction computer program. The program is a generalized steady-state and/or transient heat conduction code derived from the HEATING 3 program. (1) The program has the capability for accounting for material phase change. Thermal conductivity, density, and specific heat may be dependent upon temperature. Heat generation rates may be dependent upon position and time, and the boundary temperatures may be time dependent. Boundary conditions can be either fixed temperatures or any combination of constant heat flux, forced convection, natural convection, and radiation.

The cask configuration assumed for the steady-state analys is is shown in Figure B.1. The outer cooling fins have been rotated $90^{\circ}$ for calculational simplicity. This does not significantly affect the accuracy of the results. The ambient temperature surrounding the cask was assumed to be $50^{\circ} \mathrm{C}$. The results of the steady-state analysis are presented in Table B.1.

The configuration for the transient thermal analysis is shown in Figure B.2. It was assumed that the cask was completely immersed in a $1000^{\circ} \mathrm{C}$ fire environment for one hour. The outer cooling fins were again rotated $90^{\circ}$ for this analysis. The cask structure has been somewhat simplified for the transient thermal analysis to reduce computer program running times. The main simplification is the removal of the air gaps and the canister walls between the waste and the cavity magazine. These simplifications produce conservative results for the transient analysis. It is also assumed that the water in the neutron shield is lost through the relief valve shortly after the fire begins. 


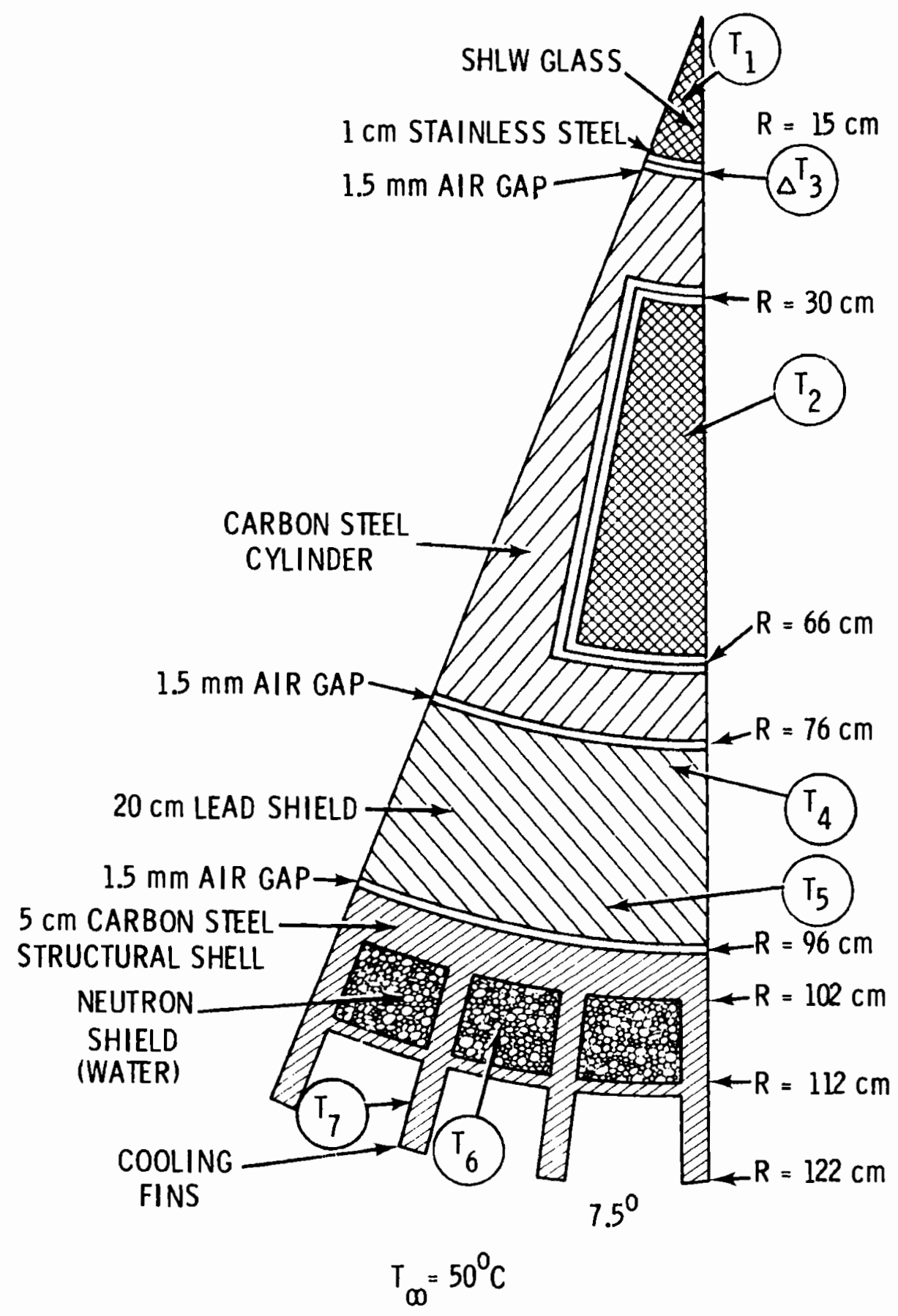

FIgURE B.1. Configuration Assumed for Steady State Thermal Analysis 


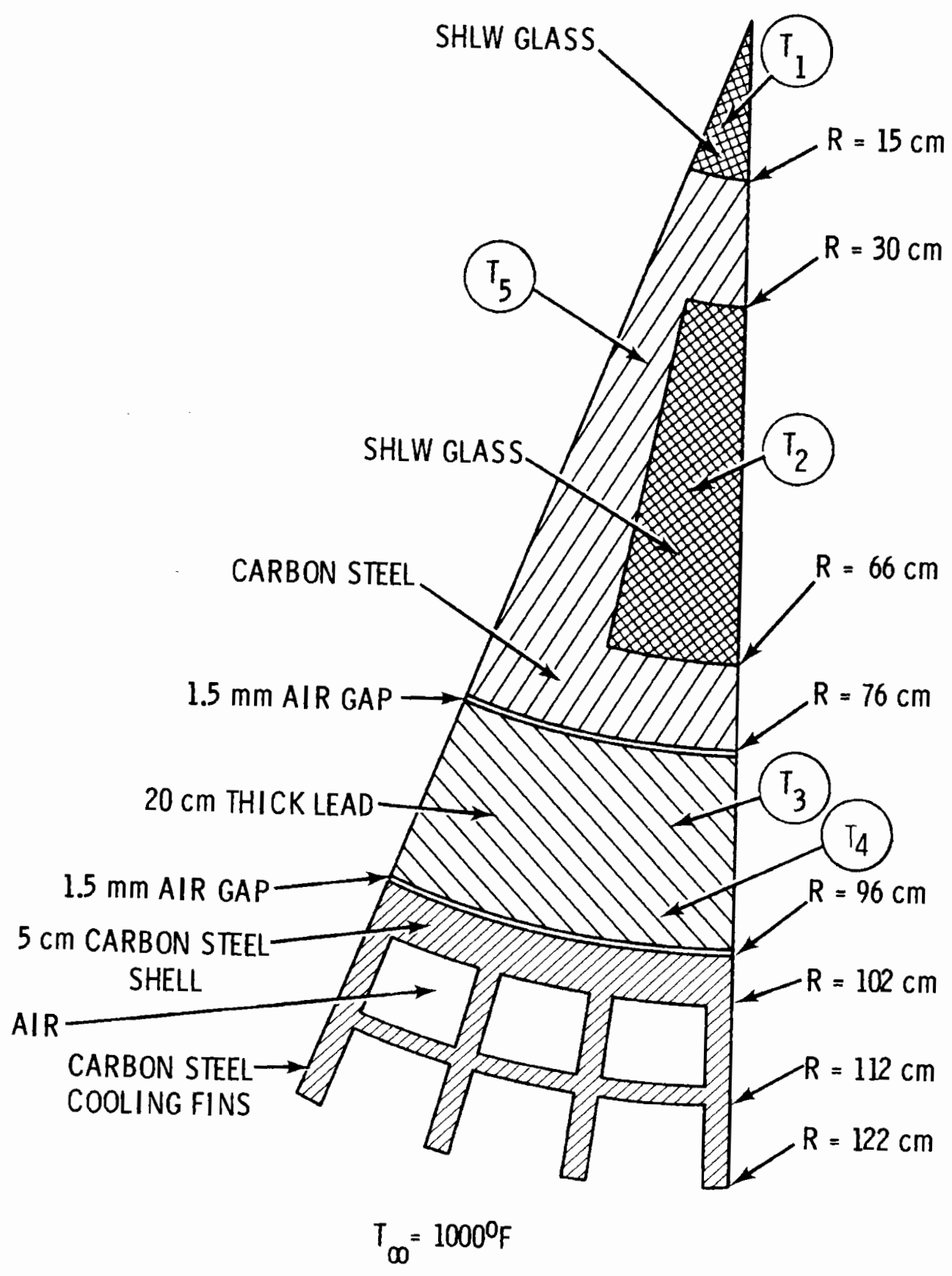

FIGURE B.2. Configuration Assumed for Transient Thermal Analys is 
TABLE B.1. Results of Steady-State Thermal Analys is

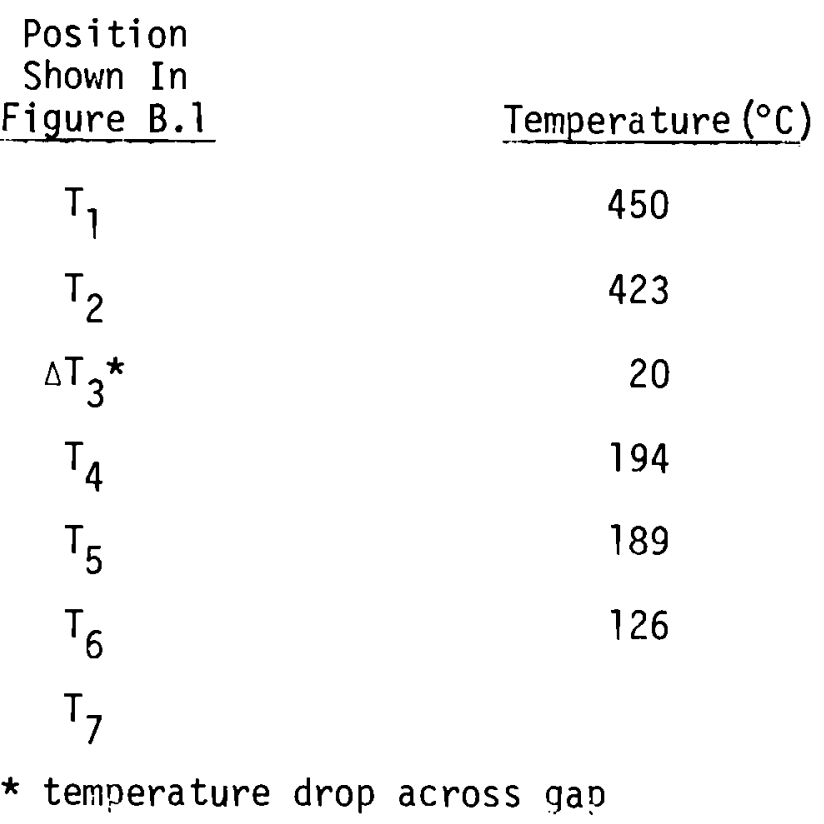

The results of the transient analysis are presented in Table B.2. The steady-state conditions shown in Table B.2 differ slightly from the more accurate calculations presented in Table B.l because of the simplified cask structure used in the transient analysis. The transient analysis shows that the waste canisters are essentially unaffected by exposure to a $1000^{\circ} \mathrm{C}$ fire for one hour. The massive cask structure can absorb most of the thermal energy from the fire without transferring it to the contents and the heat generation rate in the waste is sufficiently low that self-heating from impaired heat transfer out of canisters is not a problem in a one-hour fire. 
TABLE B.2. Results of a Transient Thermal Analysis

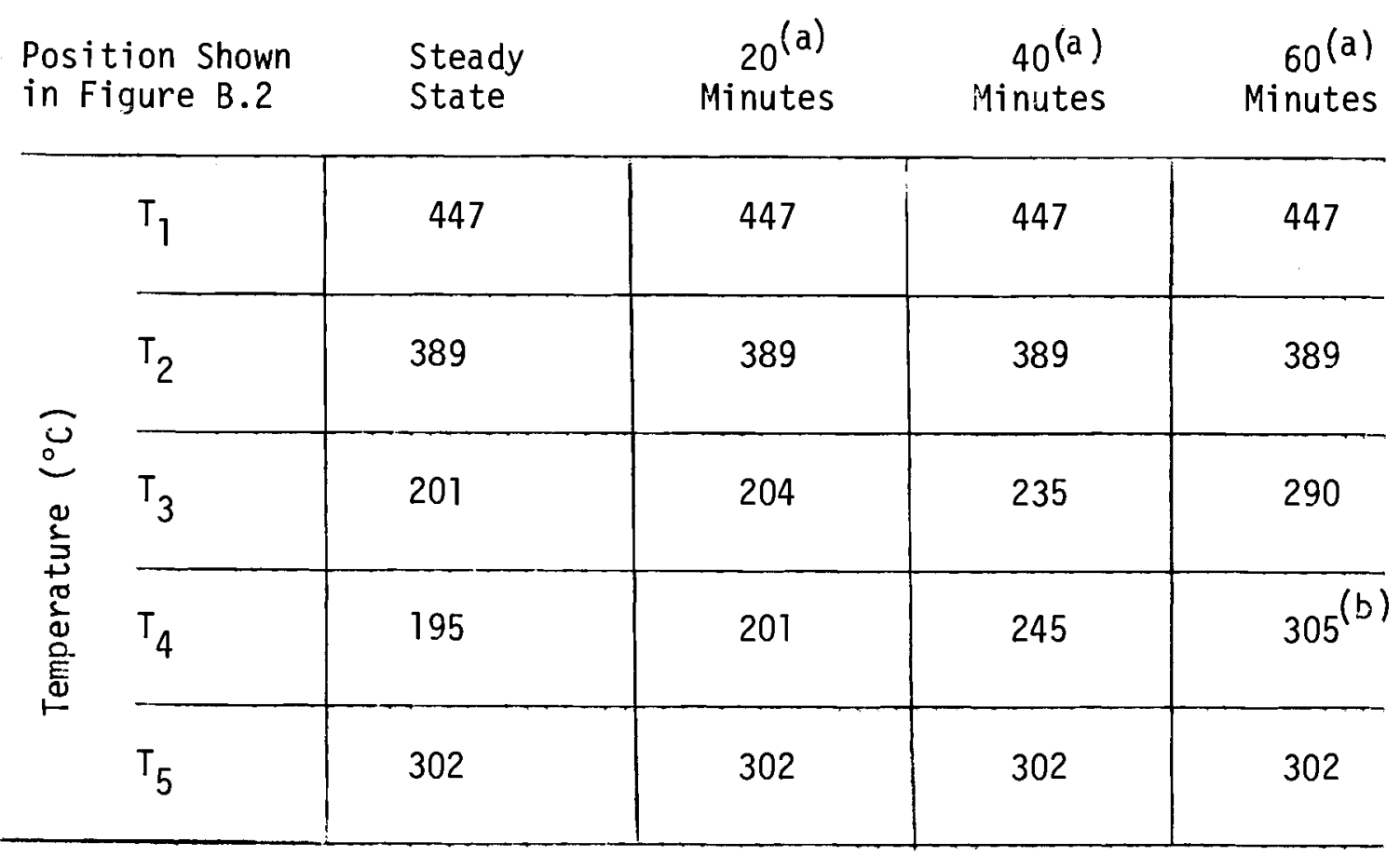

(a) Time after start of $1000^{\circ} \mathrm{C}$ fire.

(b) Outer portion of lead had begun to melt after 54 minutes.

The inner magazine of the cask was assumed to be carbon steel in both thermal analyses. The material was subsequently changed to aluminum in the conceptual design. Use of carbon steel tends to make the analyses conservative because aluminum is a better thermal conducter. Air gaps were also conservatively assumed around the SHLW canisters for the steady state analysis rather than the contacting surfaces that finally evolved in the design.

\section{REFERENCE}

1. W. D. Turner and M. Simon-Tov, Heating 3 - An IBM 360 Heat Conduction Program (ORNL-TM-3208) Oak Ridge National Laboratories, Oak Ridge, TN, February 1971. 


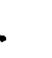




\section{APPENDIX C - Mechanical Analysis of Conceptual Cask}

The set of four hypothetical accident conditions for Type B packages are presented in Section 2.1. A discussion of the capabilities of the conceptual cask to withstand the free drop and puncture tests is presented in this appendix. The capability of the conceptual cask to withstand immersion in shallow water was not analyzed because the design of large casks provides inherent protection from immersion damage due to the seal on the closure end and the capability of the body to withstand internal pressure.

\section{C.1 PUNCTURE ANALYSIS}

Equations for prediction of incipient puncture energy in steel-shelled, lead-lined casks were developed by Nelms of ORNL. (1) For casks exceeding $75 \mathrm{~cm}$ in diameter, the following equation was derived from experiments:

$$
\begin{aligned}
\mathrm{t} & =34.6\left(\frac{\mathrm{W}}{\sigma_{B}}\right) 0.71 \\
\text { where } \mathrm{t} & =\text { shel1 thickness }(\mathrm{mm}) \\
\mathrm{W} & =\text { cask weight (metric tons) } \\
\sigma_{\mathrm{B}} & =\text { ultimate tensile strength of jacket material }\left(\mathrm{kg} / \mathrm{mm}^{2}\right)
\end{aligned}
$$

The ultimate tensile strength of the jacket (or she11) material was assumed to be $56.8 \mathrm{~kg} / \mathrm{mm}^{2}$, based on the properties of $304 \mathrm{~L}$ stainless steel. (1) The required shel1 thickness for a 120 -ton cask is $5.0 \mathrm{~cm}$, based on the expression above. This value is believed to be conservative.

The minimum shell thickness to prevent puncture in large casks was also determined by Japanese investigators from model tests. ${ }^{(2)}$ The results of the Japanese investigations that are applicable to the conceptual cask design are plotted in Figure C.1. Nelm's equation presented above is also plotted in 
the figure for comparison, and the conditions of the reference cask are indicated by dashed lines for each of the calculational methods. The minimum shell thickness determined from the Japanese data is $4 \mathrm{~cm}$. A shell thickness of $5 \mathrm{~cm}$ was selected for the conceptual cask. This value is intermediate to the shell thickness determined by the two calculations and should provide a conservative margin of safety for puncture resistance of the conceptual cask.

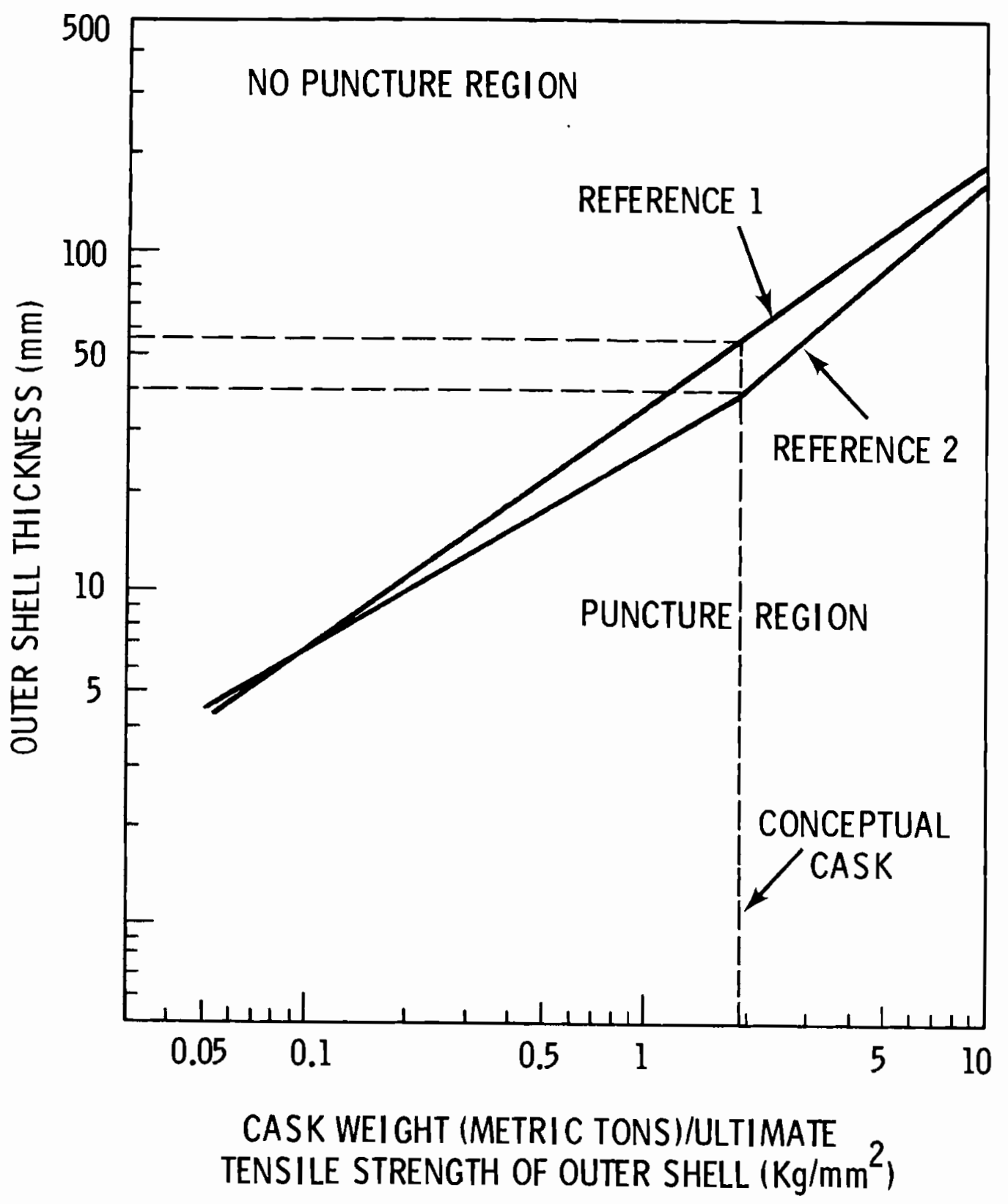

FIGURE C.1. Outer Shell Thickness vs. Weight of Cask to Cause Puncture 


\section{C.2 IMPACT ANALYSIS}

Impact limiters are normally provided external to the cask if it cannot be proven that the cask alone can survive the 30 foot drop qualification test required by federal regulations for Type B packages. The impact limiters also reduce the force levels on the contents of the cask in an accident. Most currently 1 icensed spent fuel casks use balsa wood impact 1 imiters at each end of the cask, partly because the analysis of energy absorption is straightforward.

Stainless steel fins were selected for impact limiters on the conceptual cask. The selection of fins was based partly on the simplicity of display in the models. Metallic plate impact limiters offer a disadvantage in that the tools needed to analytically examine the large displacement response have either not been satisfactorily developed or are too complex and expensive (in terms of computer time) to utilize. (3) Analytic design of the impact fins was beyond the scope of the present study. The fin configuration used in the conceptual design was derived by comparison to a currently-licensed rail cask for shipping. The IF-300 spent fuel cask manufactured by General Electric uses stainless steel fins as impact 1 imiters. (4) Comparison of the IF- 300 fin configuration and volume with the conceptual high-level waste cask indicated that a similar fin pattern and size would absorb the energy from the 30-foot free drop directly onto either end. The HLW cask weighs approximately $50 \%$ greater which would accommodate the necessary additional fin volume at each end.

Energy absorption during a corner drop of the HLW cask would require more fins along the periphery, larger fins, or structurally stiffened fins to absorb the total energy because the additional weight of the HLW cask is concentrated at the point of impact. It was assumed for the conceptual design that the closure end of the cask could absorb the additional energy without failure. Internal shock absorbers were also provided to limit the force on the waste canisters in the cask in the event that the fins "bottomed out." Further engineering analysis would be required to confirm the adequacy of the 
fin configuration presented in the conceptual design. This analysis would be performed when the cask design was being finalized for submission to the Nuclear Regulatory Commission for licensing action.

\section{3 ANALYSIS OF LIFTING AND SUPPORT TRUNNIONS}

The performance standards for the cask lifting devices (trunnions) require the system to be capable of supporting three times the weight of the cask without generating stress in excess of the yield strength of any material of the packaging. The trunnions were designed to the following guidelines recommended in the Cask Designers' Guide:

- mounted in massive steel blocks

- the base inserted at least one trunnion diameter into its socket

- use a safety factor of 4

- analyze as a short cantilever beam

The configuration used in the trunnion structural analysis is shown in Figure C.2. The trunnion is assumed to be a short cantilever beam with a force equal to one half the cask weight acting on the end. The length of the trunnion was estimated to be $14 \mathrm{~cm}$ to accommodate the lifting yoke and the support pedestals on the railcar. The required diameter $(d)$ was then determined from the following expressions:

$$
M=P 1=\frac{W}{2} \ell
$$

where $M=$ bending moment

$P=$ load

$w=$ cask weight

$1=$ trunnion length

and

$$
\sigma=\frac{M}{\mathrm{I} / \mathrm{C}}
$$

where $\sigma=$ allowable stress $=$ yield stress $/ 4$

$$
I / C=\text { Section modulus }=\frac{\pi d^{3}}{32}
$$



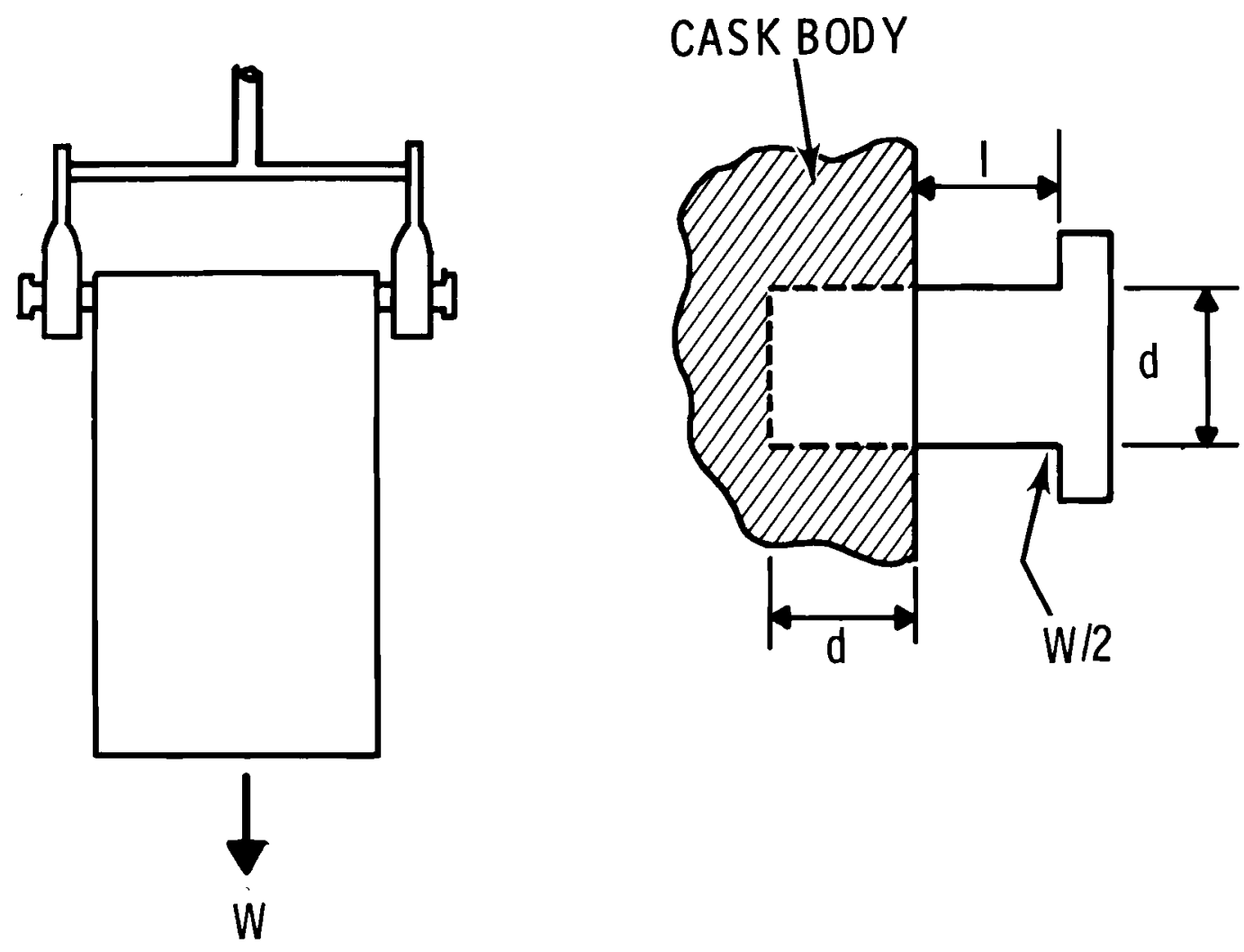

FIGURE C.2. Configuration for Trunnion Structural Analysis 
Using a yield stress for stainless steel of $5.6 \times 10^{8}$ newtons $/ \mathrm{m}^{2}$, the required trunnion diameter is $17.8 \mathrm{~cm}$.

\section{C.4 ANALYSIS OF TIEDOWNS}

The criteria for designing the tiedowns mounted on the railcar are tabulated below:

\begin{tabular}{lc} 
Direction of Force & Restraint (in g's) \\
\cline { 2 - 2 } & 10 \\
horizontal (axial) & 5 \\
horizontal (1ateral) & 2 \\
vertical &
\end{tabular}

The cask is mounted on the rail car with pedestals which enclose the lifting trunnions. The requirement for $10 \mathrm{~g}$ restraint in the axial direction would shear the trunnions from the cask body because the trunnions are designed for a maximum load of $3 \mathrm{~g}^{\prime} \mathrm{s}$. Thus, toe plates were provided on the platform of the railcar at each end of the cask body. The toe plates are designed to take the total $10 \mathrm{~g}$ axial load in the event the railcar is impacted from either the front or rear. The force from a $10 \mathrm{~g} l o a d$ would be about $10^{6}$ newtons. The toe plates would be essentially two carbon steel plates at right angles fastened togehter with gussets (as shown in the system drawings). The minimum bolt area required to fasten the toe plates to the railcar and accommodate the $10 \mathrm{~g}$ load is approximately 260 square $\mathrm{cm}$. Using a factor of safety of 2 and assuming that preloaded bolts are not used, $12-7.6 \mathrm{~cm}$ diameter high strength bolts would be required. The toe plate on the closure end of the cask is removable to permit rotation of the cask from a horizontal to a vertical position for loading and unloading operations.

The $2 \mathrm{~g}$ vertical restraint can be accommodated by two $3.8 \mathrm{~cm}$ diameter bolts at each trunnion clamp. The $5 \mathrm{~g}$ lateral restraint is analyzed below. The lateral 5"g" load is assumed to be divided equally between the 4 pedestals. Each pedestal was analyzed as a simple cantilever beam. The geometric 
configuration is shown in Figure C.3. The force on each is:

$$
\frac{\text { cask weight } \times 5 \mathrm{~g}}{4}=\frac{(110,000 \mathrm{~kg})\left(9.8 \mathrm{~m} / \mathrm{sec}^{2}\right)(5)}{4}=1.3 \times 10^{6} \text { newtons }
$$

For a cantilever beam with a concentrated load at the end, the following relationships are used:

$$
\begin{aligned}
& M_{\max }=\mathrm{P} 1 \\
& M=\text { bending moment (joules) } \\
& \mathrm{P}=1 \mathrm{ad}=1.3 \times 10^{6} \text { newtons } \\
& 1=\text { length }=1.4 \mathrm{~m} \\
& \sigma=\frac{M}{I / c} \\
& \begin{array}{l}
\left.\sigma=\text { stress (newtons } / \mathrm{m}^{2}\right) \\
M=\text { bending moment }(\text { joules) } \\
I / c=\text { section modules }\left(\mathrm{m}^{3}\right)
\end{array}
\end{aligned}
$$

The pedestals were assumed to be fabricated from mild steel plate with an allowable stress of $1.38 \times 10^{8}$ newtons $/ \mathrm{m}^{2}$. Using the relationships above, the required section modulus is $1.35 \times 10^{-2} \mathrm{~m}^{3}$ at the base of the pedestal. The inset shown in Figure $\mathrm{C} .2$ has a section modulus of $1.80 \times 10^{-2} \mathrm{~m}^{3}$ which provides a larger factor of safety. The pedestal on the rear end of the cask has additional gussets inside the vertical plate which provides an even greater factor of safety. The $\mathrm{HO}$ gage models showed a solid plate covering the gussets of the pedestals which provides a cleaner appearance. 


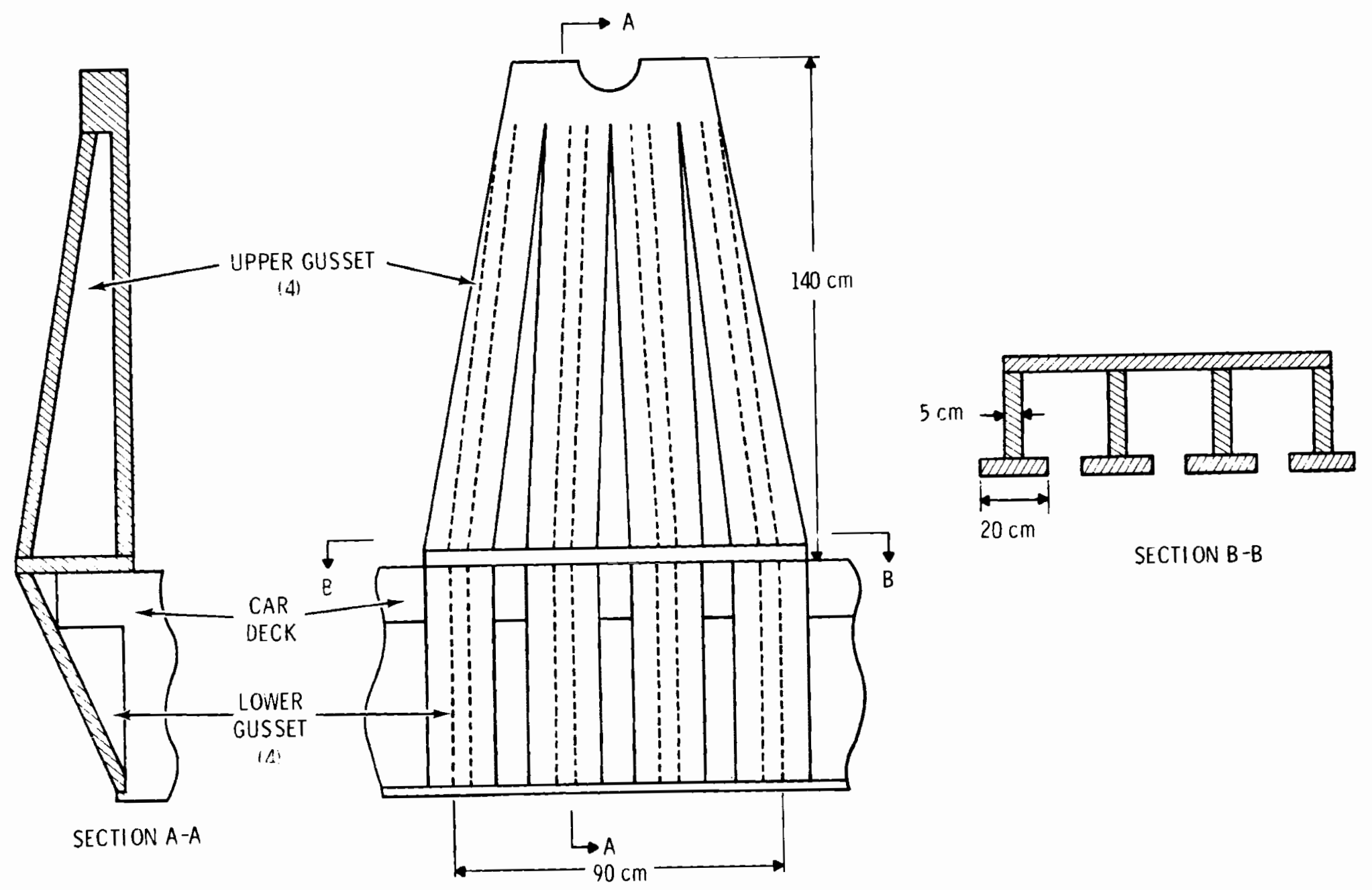

FIGURE C.3. Forward Pedestal Assembiy 


\section{REFERENCES}

1. H. A. Nelms, Structural Analys is of Shipping Casks, V.3 Effects of Jacket Physical Properties and Curvature in Puncture Resistance, (ORNL-TM-1372), Oak Ridge National Laboratories, Oak Ridge, TN, 1968.

2. I. Sakamoto, et. al., "An Experimental Study on Puncture Resistance of Spent Fuel Shipping Casks by Drop Impact Tests," Proceedings of the 4th International Symposium on Packaging and Transportation of Radioactive Materials (CONF-740901), Miami Beach, Florida, September 22-27, 1974.

3. L. I. Weingarten, Impact Energy Mitigation in LMFBR Spent Fuel Casks (SAND 76-0601), Sandia Laboratories, Albequerque, NM, February, 1977.

4. IF-300 Shipping Cask Design and Analys is Report, (NED0-10084-1), Nuclear Fuel Department, GeneraT ETectric Company, San Jose, CA, February, 1973.

5. L. B. Shappert et. a1., Cask Designers' Guide (ORNL-NSIC-68), Oak Ridge National Laboratories, 0ak Ridge, TN, February, 1970. 

No. of

Copies

OFFSITE

A. A. Churm

Chicago Patent Group

DOE Chicago Operations Office

9800 South Cass Avenue

Argonne, IL 60439

171 DOE Technical Information Center

K. A. Trickett

Division of Reactor Development and Demonstration

Department of Energy

Germantown, MD 20014

25 W. Brobst

Transportation Branch

Division of Environmental

Control Technology

Department of Energy

Washington, DC 20545

J. Counts

Transportation Branch

Division of Environmental Control Technology

Department of Energy

Washington, DC 20545

R. F. Garrison

Transportation Branch

Division of Environmental

Control Technology

Department of Energy

Washington, DC 20545

R. B. Chitwood

Division of Fuel Storage and Transfer

Department of Energy

Washington, DC 20545

J. A. Sisler

Transportation Branch

Division of Environmental

Control Technology

Department of Energy

Washington, DC 20545
No. of

Copies
E. C. Hardin, Jr.

Office of the Assistant

Secretary for Energy Technology

Department of Energy

Washington, DC 20545

R. M. Moser

DOE Chicago Operations Office

9800 South Cass Avenue

Argonne, IL 60439

W. G. O'Quinn

DOE Savannah River Operations Office

P.0. Box A

Aiken, SC 29801

N. Stetson

DOE Savannah River Operations Office

P.0. Box A

Aiken, SC 29801

L. L. Turner

DOE Savannah River Operations Office

P.0. Box A

Aiken, SC 29801

D. Davis

DOE Albuquerque Operations Office

P.0. Box 5400

Albuquerque, NM 87115

J. A. Lamb

DOE Oak Ridge Operations Office

P.0. Box E

Oak Ridge, TN 37830

J. J. Schreiber

DOE Oak Ridge Operations Office

P.0. Box E

Oak Ridge, TN 37830 
No. of

Copies

J. L. Russell

Office of Radiation Programs

AW-459, EPA

401 M St. S.W.

Washington, DC 20460

R. L. Ferguson

Director, Nuclear Energy

Programs

Department of Energy

Washington, DC 20545

T. K. Keenan

University of California

Los Alamos Scientific Laboratory

P.0. Box 1663

Los Alamos, NM 87545

T. A. Butler

University of California

Los Alamos Scientific Laboratory

P.0. Box 1663

Los Alamos, NM 87545

L. Benner

National Transportation Safety Board

Department of Transportation

Washington, DC 20594

Ichiro Yabe

Nuclear Safety Research

Association

Room 1037, National Press

Building

14 th and F St. N.W.

Washington, DC 20004

P. J. Eicker

Sandia Laboratories, Livermore

Livermore, CA 94550

J. W. Langhaar

E. I. Dupont de Nemours \& Company

Savannah River Plant

Aiken, SC 29801

L. D. Santman

Materials Transportation Bureau

Department of Transportation

2100 Second St. S.W.

Washington, DC 20590
No. of

Copies

Dr. H. C. Thompson

Battelle Memorial Institute

Washinaton Operations

20301 M St. N.W.

Washington, DC 20036

W. Rowe

Environmental Protection Agency

401 M St.

Washington, DC 20460

A. J. Nertney

Aerojet Nuclear Company

550 2nd St.

Idaho Falls, ID 83401

C. Starr

Electrical Power Research Inst.

P.0. Box 10412

Palo Alto, CA 94304

C. Comar

Electrical Power Research Inst.

P. 0. Box 10412

Palo Alto, CA 94304

E. Zebrowski

Electrical Power Research Inst. P.0. Box 10412

Palo Alto, CA 94304

R. Williams

Electrical Power Research Inst.

P.0. Box 10412

Palo Alto, CA 94304

Prof. Norman C. Rasmussen

Massachusetts Institute of Technology

Cambridge, MA 02139

S. H. Sutherland

Sandia Laboratories

P.0. Box 5800

Albuquerque, NM 87115

J. T. Foley

Sandia Laboratories

P.0. Box 5800

Albuquerque, NM 87115 
No. of

Copies

J. Freedman

Sandia Laboratories

P.0. Box 5800

A1buquerque, NM 87115

W. F. Hartmann

Sandia Laboratories

P.0. Box 5800

A1buquerque, NM 87115

R. M. Jefferson

Sandia Laboratories

P.0. Box 5800

A1buquerque, NM 87115

R. Luna

Sandia Laboratories

P.0. Box 5800

A1buquerque, NM 87115

T. G. Priddy

Sandia Laboratories

P.0. Box 5800

Albuquerque, NM 87115

R. Yoshimura

Sandia Laboratories

P.0. Box 5800

A1buquerque, NM 87115

R. F. Barker

Nuclear Regulatory Commission

Washington, DC 20555

C. B. Bartlett

Nuclear Regulatory Commission

Washington, DC 20555

R. B. Minogue

Nuclear Regulatory Commission

Washington, DC 20555

C. McDonald

Nuclear Regulatory Commission

Washington, DC 20555

M. J. Steindler

Argonne National Laboratory

9700 South Cass Avenue

Argonne, IL 60439
No. of

Copies

D. S. Joy

Union Carbide Corporation

Oak Ridge National Laboratory

P.0. Box $X$

Oak Ridge, TN 37830

Bi11 Pardue

Battelle Memorial Institute

Office of Nuclear Waste

Isolation

505 King Avenue

Columbus, $\mathrm{OH} 43201$

R. A. Robinson

Battelle Memorial Institute

Office of Nuclear Waste

Isolation

505 King Avenue

Columbus, $\mathrm{OH} 43201$

Atomics International

8900 DeSoto Avenue

Conoga Park, CA 91304

A. L. Kaplan

General Electrical Co.

Nuclear Fuel Division

P.0. Box 780

Wilmington, NC 28401

R. D. Seagren

Union Carbide Corporation

Oak Ridge National Laboratories

P.0. Box $X$

Oak Ridge, TN 37830

L. Shappert

Union Carbide Corporation

Oak Ridge National Laboratories

P.0. Box X

Oak Ridge, TN 37830

J. Duckworth

Nuclear Fuel Service, Inc.

P.0. Box 124

West Va11ey, NY 14171

G. L. Stukenbroeker

N. L. Industries, Inc.

Nuclear Transportation Dept.

P.0. Box 2046

Wilmington, DE 19899 
No. of

Copies

J. R. Marshall

Union Carbide Corporation

Oak Ridge National Laboratory

P.0. Box $X$

Oak Ridge, TN 37830

M. M. Heiskel

Union Carbide Corporation

Oak Ridge National Laboratory

P.0. Box $X$

Oak Ridge, TN 37830

H. G. Shealy

Bureau of Radiological Heal th

South Carolina Department of Health and Environmental Control

Columbia SC 29405

J. S. Corbett

ChemNuclear Systems, Inc.

P.0. Box 1866

Bellevue, WA 98009

J. A. Hebert

Battelle Seattle Research Center

P.0. Box 5395

Seattle, WA 98105

P. T. Tuite

Hittman Nuclear and Development Corporation

9190 Red Branch Rd.

Columbia, MD 21045

D. A. Edling

Mound Laboratories

P.0. Box 32

Miamisburg, $\mathrm{OH} 45342$

J. W. Doty

Mound Laboratories

P.0. Box 32

Miamisburg, $\mathrm{OH} 45342$

D. Okrent

Department of Engineering and Applied Science

University of California

Los Angeles, CA 90024
No. of

Copies

2 L. Forrest

California Energy Resources

Conservation and Development

Commission

1111 Howe Avenue

Sacramento, CA 95825

R. H. Jones

Transportation Systems

Nuclear Energy Programs

Division

General Electric Company

175 Curtner Avenue

San Jose, CA 95125

M. Gordon

Atomic Industrial Forum

7101 Wisconsin Ave.

Washington, DC 20014

A. L. Babb

Department of Nuclear Engineering

Benson $\mathrm{Hall}$

University of Washington

Seattle, WA 98195

W. S. Fellows

Southern Interstate Nuclear

Board

One Exchange Place, Suite 1230

Atlanta, GA 30341

D. G. Maxwe 11

N. L. Industries

Nuclear Division

Foot of West Street

Wilmington, DE 19801

W. R. Teer

Transnuclear Inc.

One N. Broadway

White Plains, NY 10601

J. L. Ridihalgh

Ridihalgh, Eggers \& Associates

2112 Iuka Avenue

Columbus, $\mathrm{OH} 43201$ 
No. of

Copies

S. C. Cohn

Teknekron

4701 Sangamore Rd.

Washington, DC 20016

S. Aoki

Research Laboratory for Nuclear Reactors

Tokyo Institute of Technology

Ookayama, Meguroku, Tokyo 152 JAPAN

A. Onedera

Hitachi Shipbuilding and Engineering Co., Ltd.

5-4 Sakurajima, Kitano-cho

Konohana-ku, 0saka-shi

JAPAN

K. I keda

Science and Technology Agency

2-2-1 Kasumigaseki,

Chiyoda-ku, Tokyo

JAPAN

S. A. Mayman

Fuel Recy'cle Waste

Management Program

Whiteshell Nuclear Research

Establishment

Pinewa, Manitoba ROE ILO

CANADA

Ake Hultgren

$A B$ Atomenergi, Studsvik

Fack

S-611 ol Nyköping 1

SWEDEN

B. Gustafson

c/o Ake Hultgren

AB Atomenergi, Studsvik

Fack

S-611 ol Nyköping 1

SWEDEN

R. W. Peterson

Battelle Memorial Institute

Office of Nuclear Waste Isolation

505 King Avenue

Columbus, $\mathrm{OH} 43201$
No. of

Copies

A. Carson

General Electric Company

175 Curtner Avenue

San Jose, CA 95125

R. A. Koynenburg

University of California

Lawrence Livermore Laboratories

P.0. Box 808

Livermore, CA 94551

R. E. Best

Nuclear Assurance Corporation

24 Executive Park West

Atlanta, GA 30329

W. E. Pollock

Oregon Department of Energy

Salem, OR 97301

W. M. Rogers

Western Interstate Nuclear Board

1300 Carr

Denver, C0 80226

G. P. Jones

University of Southern

California

University Park

Los Angeles, CA 90007

E. A. Straker

Science Applications, Inc.

P.0. Box 2351

La Jolla, CA 92038

R. C. Erdman

Science Applications, Inc.

2680 Hanover St.

Palo Alto, CA 94304

G. Waymire

Exxon Nuclear Company, Inc.

P.0. Box 3990

MS 8A-68

Seattle, WA 98124

Hubert Baker

E.I. DuPont de Nemours \& Co.

Savannah River Laboratory

Aiken, SA 29801 
No. of

Copies

C. A. Mayer

Tri-State Motor Transit

Co., Inc.

P.0. Box 113

Joplin, MO 64801

J. Edlow

Edlow International

1100 17th Street N.W.

Washington, DC

W. F. Black

Hazardous Materials Branch

Federal Railroad Administration

Department of Transportation

Washington, DC

Dr. C. Furber

Research and Test Department

Association of American Railroads

1920 L Street, N.W.

Washington, DC 20036

R. R. Raw 1

Materials Transportation Bureau

U.S. Department of Transportation

Washington, DC 20545

\section{ONSITE}

6 DOE Richland Operations Office

T. A. Bauman

R. B. Goranson

P. E. Lamont

J. M. Peterson

H. E. Ransom

D. J. Squires

\section{Rockwell Hanford Company}

W. G. Bevan

W. M. Harty

D. D. Woodrich

3 United Nuclear Industries, Inc.

J. A. Adams

P. A. Crosetti

T. E. Dabrowski
No. of

Copies

2 Washington Public Power Supply System

G. F. Bailey

J. B. Vetrano

3 Exxon Nuclear Company, Inc.

E. Mays

R. Nilsen

R. K. Robinson

Hanford Engineering Development Laboratory

A. W. DeMerschman

58 Pacific Northwest Laboratory

W. B. Andrews

W. J. Bair

C. L. Brown

N. M. Burleigh (25)

S. H. Bush

N. E. Carter

J. G. DeSteese

H. K. Elder

A. L. Franklin

C. A. Geffen

R. J. Hall

H. Harty

H. L. Henry

W. S. Kelley

S. N. Liu

J. L. MCElroy

T. I. McSweeney

J. Mishima

E. S. Murphy

P. L. Peterson

A. M. Platt

R. E. Rhoads

J. W. Voss

E. C. Watson

R. D. Widrig

L. D. Williams

W. K. Winegardner

Technical Information (5)

Publishing Coordination (2) 